\title{
COSMIC AIRBURST ON DEVELOPING ALLERØD SUBSTRATES (SOILS) IN THE WESTERN ALPS, MT. VISO AREA
}

\author{
William C. Mahaney ${ }^{1,2 *}$, Allen West $^{3}$, Alison Milan², David H. Krinsley ${ }^{4 *}$, Peeter Somelar ${ }^{5}$, \\ Stephane Schwartz ${ }^{6}$, Michael W. Milner ${ }^{7}$, Christopher C.R. Allen ${ }^{8}$ \\ ${ }^{1}$ Quaternary Surveys, 26 Thornhill Ave., Thornhill, Ontario, Canada, L4J1J4 \\ ${ }^{2}$ Department of Geography, York University, 4700 Keele St., North York, Ontario, Canada, M3J1P3, \\ e-mail: arkose41@gmail.com; Alison.milan@edu.yorku.ca \\ ${ }^{3}$ Geo-Science Consulting, 830 S. Dewey Rd., Dewey, Arizona, U.S., 86327, e-mail: Allen7633@aol.com \\ ${ }^{4}$ Department of Geological Sciences, University of Oregon, Eugene, Oregon, U.S. 97403-1272 ${ }^{* *}$ David Krinsley deceased \\ November 5, 2017 \\ ${ }^{5}$ Department of Geology, Tartu University, Tartu, Estonia, e-mail: psomelar@ut.ee \\ ${ }^{6}$ Université Grenoble Alpes, ISTerre-UMR 5275, F-38041 Grenoble, France, e-mail: stephane.schwartz@ujf-grenoble.fr \\ ${ }^{7}$ MWM Consulting, 182 Gough Ave, Toronto, Ontario, Canada, M4K 3P1, e-mail: michael.milner@sympatico.ca \\ ${ }^{8}$ Queens University Belfast, School of Biological Sciences, Belfast BT7 1NN, UK, e-mail: c.allen@qub.ac.uk \\ * corresponding author
}

\begin{abstract}
Although much has been written about a cosmic impact event in the Western Alps of the Mt. Viso area, the event closely tied with the Younger Dryas Boundary (YDB) of $12.8 \mathrm{ka}$ and onset of the Younger Dryas (YD), the affected land surface is considered to contain a similar black mat suite of sediment found on three continents. While work elsewhere has focused on recovered sediment from lake and ice cores, buried lacustrine/alluvial records, and surface glacial and paraglacial records, no one has traced a mountain morphosequence of deposits with the objective of investigating initial weathering/ soil morphogenesis that occurred in ice recessional deposits up to the YDB when the surface was subjected to intense heat, presumably, as hypothesized by Mahaney et al. (2016a) from a cosmic airburst. With the land surface rapidly free of ice following glacial retreat during the Bølling-Allerød interstadial, weathering processes $\sim 13.5$ to 12.8 ka led to weathering and soil morphogenesis in a slow progression as the land surface became free of ice. To determine the exposed land character in the mid- to late-Allerød, it is possible to utilize an inverted stratigraphic soil morphogenesis working backward in time, from known post-Little Ice Age (LIA) (i.e. time-zero) through LIA ( $\sim 0.45$ to $\sim 0.10 \mathrm{ka})$, to at least the middle Neoglacial $(\sim 2 \mathrm{ka})$, to answer several questions. What were the likely soil profile states in existence at the end of the Allerød just prior to the cosmic impact/airburst (YDB)? Assuming these immature weathered regolith sections of the Late Allerød approximated the $<1$ ka old profiles seen today, and assuming the land surface was subjected to a hypothesized instant temperature burst from ambient to $\sim 2200^{\circ} \mathrm{C}$ at $\sim 12.8 \mathrm{ka}$, what would be the expected effect on the resident sediment? To test the mid-LG (YDB) to YD relationship we analyzed the paleosols in both suites of deposits - mid-LG to YD - to test that the airburst grains are restricted to Late Allerød paleosols and using relative-age-determination criteria, that the overlapping YD to mid-LG moraines are closely related in time. These are some of the questions about the black mat that we seek to answer with reference to sites in the upper Guil and Po rivers of the Mt. Viso area.
\end{abstract}

Key words: Black Mat impact/airburst; Reconstructed soil at time of YDB; mid-LG-YD paleosol Sedimentary products of cosmic impact/glacial recession.

Manuscript received 20 September 2017, accepted 28 February 2018

\section{INTRODUCTION}

Research (Kennett et al., 2015; Mahaney et al., 2016a) on the interrelationship of mid-LG and YD sediment gen- esis has been undertaken on three continents by a legion of workers, some in favor of a cosmic connection to the resurgence of YD ice (Firestone et al., 2007; Kennett et al. 2007, 2009; Wittke et al., 2013), others opposed (Van 

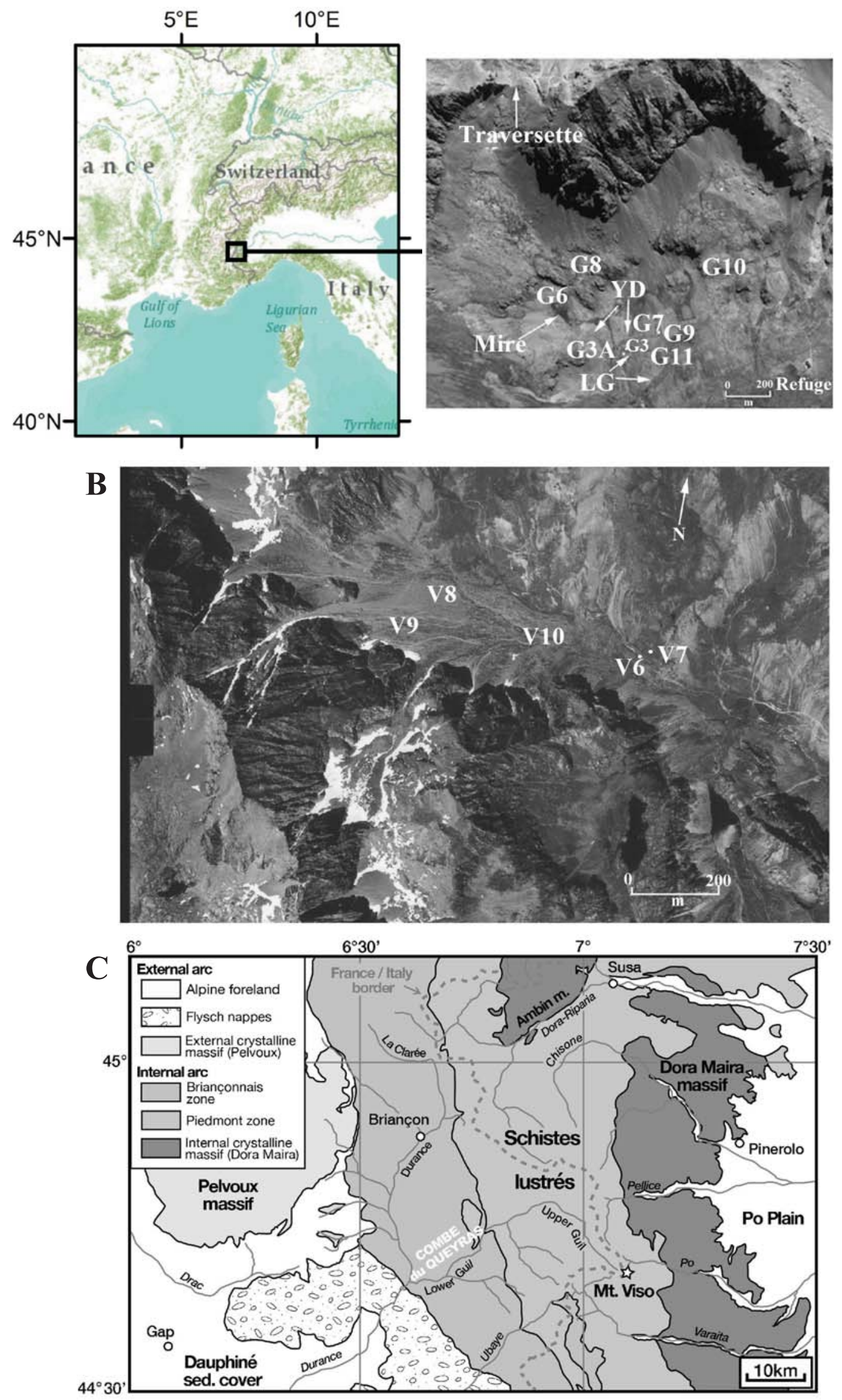

Fig. 1. A, Location of sites in mid-LG moraines in the Guil valley, Mt. Viso (3841 m asl) area. YD sites - G1 and G2 - are described and discussed in Mahaney et al.(2016a); B, Site locations of mid-LG recessional moraines (V6, 7 and 10 equivalent to G3, 3A, 9 and 11 in A) and rockfall (V8 is mid-Neoglacial; V9 is mid-LG); C, Geological map of the Internal alpine arc showing relationship between the main tectonic units. 

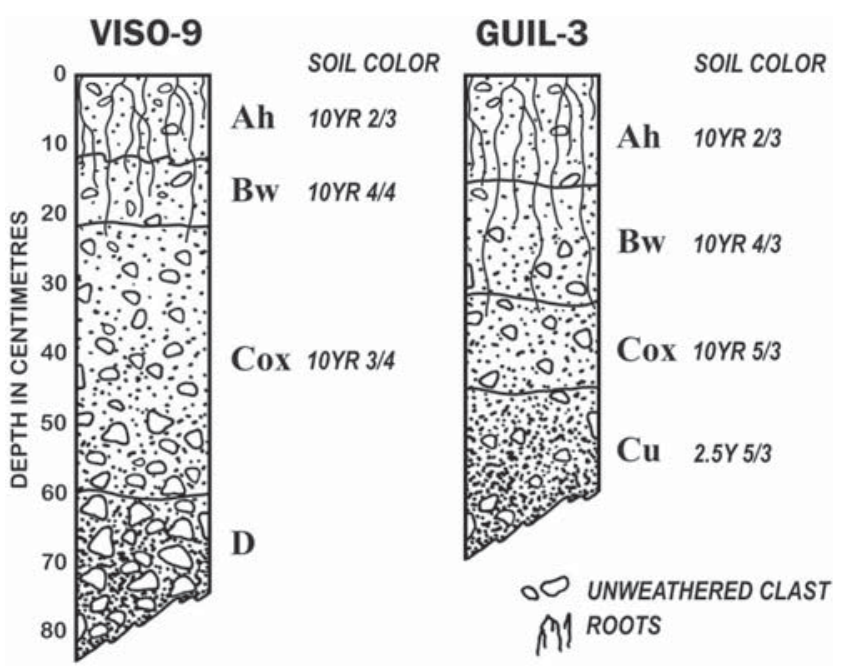

Fig. 2. Typical profiles in the upper Guil (GUIL-3) and upper Po (VISO9) catchments. Some profiles have sufficient matrix sediment to qualify as $\mathrm{Cu}$ horizons; others are an open network of coarse clastic sediment termed ' $\mathrm{D}$ '. Morphogenetic details on these and other paleosols in the Guil-Po corridor are in Mahaney and Keiser (2013) and Mahaney et al. (2016a).

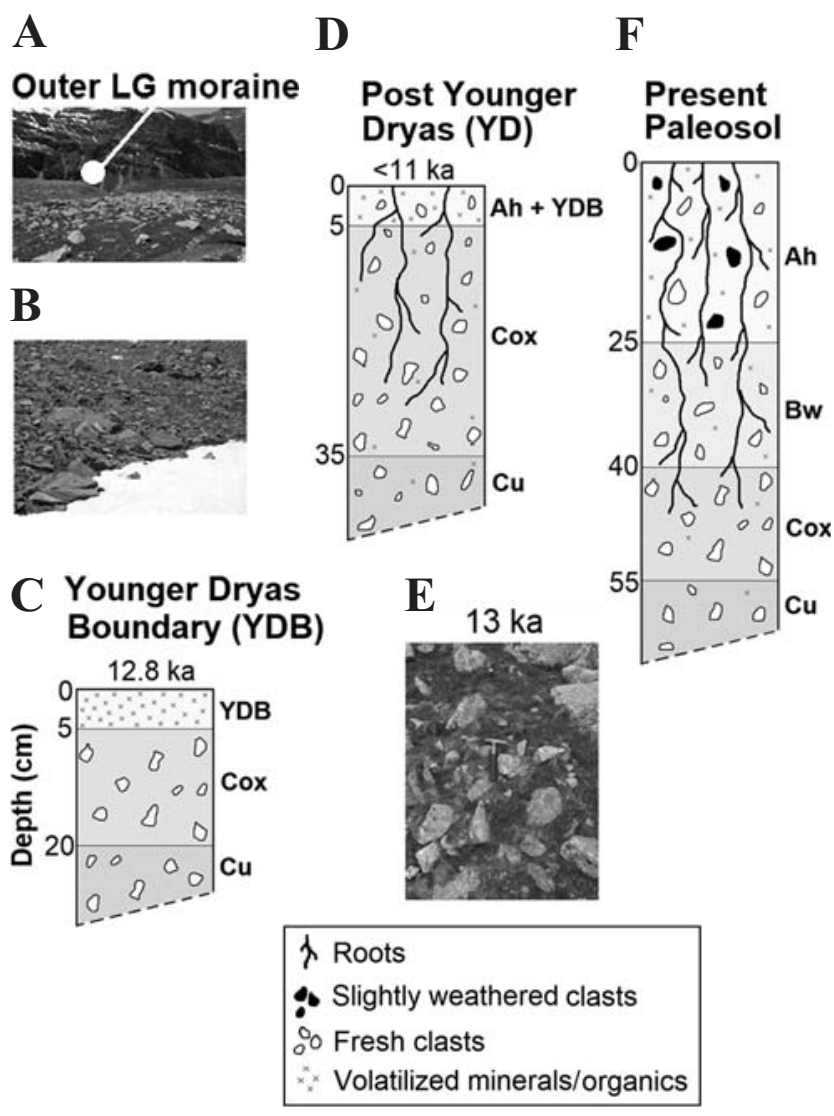

Fig. 3. Projected sequence of soils existing at the termination of the Allerød Interstadial, onset of the YDB, termination of the YD and projection of the paleosol development to the present. A - View to the WSW across the mid-LG ground moraine to the outer recessional moraine; B - Probable land surface at the end of the Allerød Interstadial ( 13 ka) using the post-LIA surface as a proxy with $\mathrm{C}(\mathrm{ox}) / \mathrm{Cu}$ profile development similar to the Pre-impact airburst event; C - YDB transformed existing soil at the initial weathering stage; D - $<$ YD soil in mid-LG surface with developing Bw horizons ( 11 ka); E - Representative mid-LG sediment surface today; $\mathrm{F}$ - mid-LG paleosol today. der Hammen and Van Geel, 2008; Haynes et al., 2010; Broecker et al., 2010; Meltzer et al., 2014), and despite attempts to establish a soil/paleosol chronosequence leading up to the YDB in the Guil catchment (Mahaney et al., 2016a, 2017) of France, no one has attempted to reconstruct the weathering sequence, which establishes the physico-mineral-chemical character of the soil profiles in existence at time of impact/airburst, i.e. end of the Allerød Interstadial or pre-YDB. In effect, this quest is only possible in the Mt. Viso area of Italy and France (Fig. 1A and B) because soil weathering system states from post-LIA, LIA, and middle Neoglacial ages are known and weathering soil states can be reconstructed from time zero to $\sim 2 \mathrm{ka}$ from the chronosequence established by Mahaney et al. (2016a). To understand the grade of weathering/soil development in existence at time of the impact event (YDB), it is necessary to establish the time trend from $\sim 15$ to $\sim 13 \mathrm{ka}$, using time-inverted data - profile expression, chemical and mineral parameters - from a soil chronosequence with pedons ranging from time zero to $\sim 2 \mathrm{ka}$ (Mahaney et al., 2016a). Admittedly, with the impact/airburst sediments in fact cosmically linked (Mahaney and Keiser, 2013; Mahaney et al., 2013b, 2016a, 2017), with ages that are controlled by site location in Late Allerød sediment complexes, their YD correlation comes from stratigraphic relationships of $\mathrm{YD}$ moraine overlapping Late Allerød deposits, not from radiocarbon dated sections. The cosmic evidence, however, indicates wildfires covered an area of at least $\sim 20 \mathrm{~km}^{2}$ (Mahaney et al., 2016a), and the mid-LG sediments affected date to well within the limits of the only major global biomass burning event dated elsewhere to the YDB interval (Wolbach et al., 2018a, b).

Such open soil systems as existed at the time of the airburst/impact (YDB) were abruptly terminated, buried or greatly altered, indeed, pyrometamorphosed (Grapes, 2010) by high heat and low pressure that was presumably produced by the cosmic impactor or airburst. The YDB event reversed the solar warming trend that occurred following the demise of Würm ice during the Bølling-Allerød Interstadial (Oldest and Older Dryas pollen zones), with the transition (YDB) producing colder conditions, change to positive glacial budgets and the onset of a $\sim 1.2 \mathrm{kyr}$ glacial advance termed the Younger Dryas (YD).

The YD, last interstade of the Late Glacial, is a term coined by Andersson (1896) and Hartz and Milthers (1901). In response to a spike in Dryas octopetala from Swedish and Danish pollen records While theories abound as to solar or terrestrial causes of the YD and relation to a preYDB cooling downturn just prior to $13 \mathrm{ka}$ (Inter-Allerød cool period; Thiagarajan et al., 2014; Ralska-Jasiewiczowa et al. 2001), the close correlation in timing of the impact/ airburst-YD events leans in a direction of cause and effect rather than mere coincidence. Using physico-mineralchemical evidence from sediment weathering, ranging from time-zero to middle Neoglacial time, coupled with an inverse 2000-yr weathering trend under somewhat cooler/ drier climate during the Bølling-Allerød ( 15 to $\sim 13 \mathrm{ka})$, an attempt is made here to reconstruct the character of 


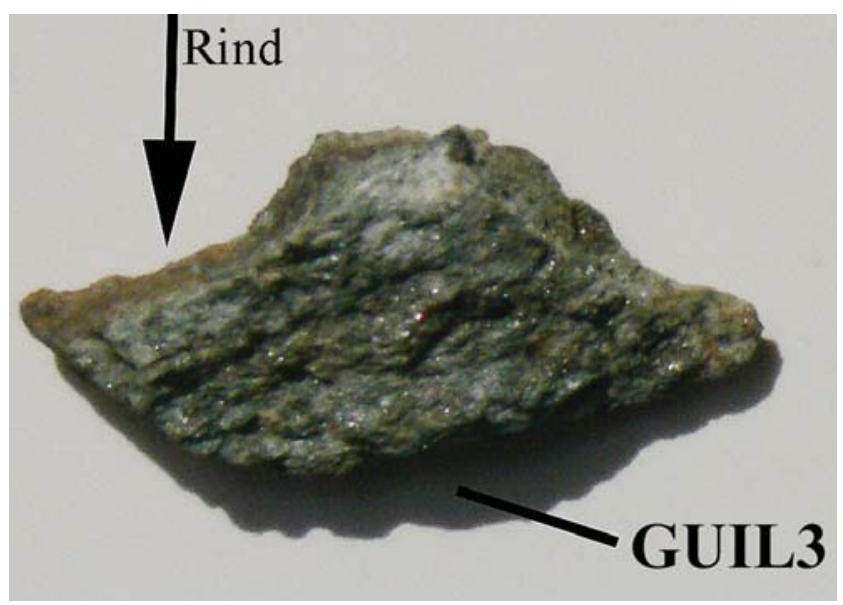

Fig. 4. Weathering rind from site GUIL-3 with variable thickness ranging from zero to $3 \mathrm{~mm}$, the upper part of the clast facing upward in the top of the G3 paleosol body. While no carbonized surface is visible in the macrophotograph, carbon spherules are known to exist within the top $0.5 \mathrm{~mm}$ of the rind.

the weathered landscape at time of the YDB $(\sim 12.8 \mathrm{ka})$. Considering that the mid-LG (Late Allerod) land surface was subjected to erosion that was stronger during the YD, aggressive decanting of meltwater rearranged moraines, cut channels and flattened crests to some degree, all of which led to surface sediment transference to lower paleosol horizons. Erosion was rather less aggressive following the YD.

This report discusses deposits and soils at time of impact/airburst and the aftermath of soil evolution leading to the morphogenesis of paleosols dating from the Late Allerød and from the YD. The archive of impact/airburst effects on soil at time of the YDB, deposit erosion, surface weathering rinds and evolution to full paleosols in existence today leads to an understanding of the full magnitude of the event. In addition, we summarize steps taken to determine if the impact/airburst left a microbiological stamp in the metagenomic structure of bacteria resident in the mid-LG paleosols today and its relation to another well documented cosmic airburst/impact in the Andes of northwestern Venezuela (Mahaney et al., 2013c).

\section{REGIONAL GEOLOGY}

The Guil Glacier flowing toward the west from the flanks of Mt. Viso (3841 m asl.), tributary to the Durance Glacier, reached its furthest extent near Sisteron in France (485 m asl.) at $130 \mathrm{~km}$ from Mt. Viso where end moraine was deposited upon a complex succession of glacial and lacustrine sediment, all undated but presumably extending beyond $100 \mathrm{ka}$ (Cossart et al., 2010) and possibly into the middle Pleistocene. The catchment extends to the FranceItaly water divide (Fig. 1C), with headwaters along the western slopes of Mt. Viso (Mahaney and Keiser, 2013). From Sisteron to near the junction of the Durance/Guil catchments and through the Combe du Queyras and the lower Guil Valley to near $2400 \mathrm{~m}$ asl, the lack of reces- sional moraines indicates ice retreat was rapid, probably occurring in just under two millennia. Ice vacated the lower Durance Valley starting ca. $15 \mathrm{ka}$, retreating rapidly into the Briançonnais area, the only chronology coming out of the Clarée Valley, 40-km northwest of the upper Guil Catchment (Cossart et al., 2010). Despite the lack of ${ }^{14} \mathrm{C}$ and CRE ages for the lower Durance and lower Guil Valley, the first such moraine stillstands occur at $\sim 2400$ to $\sim 2500$ $\mathrm{m}$ asl, and these mark a pause in the retreat phase of the Guil ice, presumably near the mid to late Allerød where a doublet moraine set is situated, the innermost deposit partially buried by a YD moraine sourced from the Col de la Traversette ( $\sim 3000 \mathrm{~m}$ asl) and several smaller cirques along the west flank of Mt. Viso.

The warming that occurred during the Bölling and Allerød inferred from palynological data shows a vegetation drift from birch-pine woodland earlier following deglaciation to mixed pine-summergreen oak forest in the forelands of the Southern Alps (Finsinger et al., 2011). The robust population dynamics of the oak population is considered to have started in the Early Bölling and on into the Allerød, partly in response to increasing summer temperature and lengthening growing season, finally ending with loss of territory upon the onset of cooling in the latest Late Glacial, i.e. the YD. The climatic inferences referenced in this work are based on correlation with two micro-tephras bracketing the YD at Lago Piccolo di Avigliana in northern Italy, the oldest (LST) dated just prior to $\sim 12.8 \mathrm{ka}$, the normal age of onset for the YDB, and the youngest (VA) $12.2 \mathrm{ka}$. These ${ }^{14} \mathrm{C}$ dated pollen time-lines are broadly equivalent to the relative age assessments in the Guil Valley as discussed below.

The Guil Valley crosscuts the internal arc of the Western Alps (Fig. 1C), which formed by juxtaposition of continental and oceanic rocks, derived from the distal European margin (Briançonnais zone) and the oceanic domain (Piedmont zone). These tectonic units, formed from closure of the Tethyan Ocean from Late Cretaceous to the Oligocene (Dumont et al., 2012), and represent a paleo-subduction zone deformed and metamorphosed under high-pressure-low-temperature conditions (Tricart and Schwartz, 2006; Schwartz et al., 2013). This paleo-subduction complex was later exhumed and deformed again during the Oligocene collision (Lardeaux et al., 2006; Schwartz et al., 2009).

The upper Guil Valley (Fig. 1C), carved into the Piedmont zone generated a landscape characterized by monotonous high cliffs and slopes exhibiting a large volume of metamorphosed marl-rich sediments highly deformed, forming the so-called "schistes lustrés" (Fig. 1C), contributed minerals to both the Late Allerød and YD sediments discussed here. These soft-sediments enclosed lenses of more resistant lithologies such as gabbros, basalts, serpentinized peridotites and dolomites with various sizes from metric to kilometric scale. In detail, the schistes lustrés mineral complex corresponds with the sedimentary accretionary wedge derived from Tethyan oceanic sediments (Lemoine et al., 1986), and records blueschist facies conditions (Schwartz et al., 2013), whereas the Mt. Viso and the Col de la Traversette are mainly composed of mafic and 
Table 1. Organic carbon distributions in the post and preLIA soils and airburst affected paleosols of Late Glacial age in the Guil/Po catchments, Mt. Viso area, France and Italy.

\begin{tabular}{|c|c|c|c|}
\hline Site & Horizon & Depth $(\mathrm{cm})$ & Organic Carbon (\%) \\
\hline G6 & $\mathrm{Cu}$ & $0-20$ & 0.31 \\
\hline G8 & Cox & $0-15$ & 1.03 \\
\hline G10 & $\mathrm{C}$ & $0-18$ & 1.14 \\
\hline \multirow{3}{*}{ G7 } & $\mathrm{Ah}$ & $0-4$ & 4.80 \\
\hline & C1ox & $4-15$ & 1.54 \\
\hline & C2ox & $15-25$ & 1.29 \\
\hline \multirow{3}{*}{ V8 } & $\mathrm{Ah}$ & $0-10$ & 6.49 \\
\hline & $\mathrm{C}$ & $10-22$ & 1.60 \\
\hline & $\mathrm{Cu}$ & $22+$ & 0.69 \\
\hline \multirow{4}{*}{ G3 } & $\mathrm{Ah}$ & $0-16$ & 2.45 \\
\hline & $\mathrm{Bw}$ & $16-32$ & 1.11 \\
\hline & Cox & $32-45$ & 0.38 \\
\hline & $\mathrm{Cu}$ & $45+$ & 0.28 \\
\hline \multirow{4}{*}{ G3A } & $\mathrm{Ah}$ & $0-13$ & 6.98 \\
\hline & $\mathrm{Bw}$ & $13-25$ & 1.91 \\
\hline & Cox & $25-39$ & 0.80 \\
\hline & $\mathrm{Cu}$ & $39+$ & 0.27 \\
\hline \multirow{4}{*}{ G9 } & $\mathrm{Ah}$ & $0-12$ & 3.17 \\
\hline & $\mathrm{Bw}$ & $12-28$ & 0.95 \\
\hline & Cox & $28-41$ & 0.58 \\
\hline & $\mathrm{D}+$ & & \\
\hline \multirow{4}{*}{ G11 } & $\mathrm{Ah}$ & $0-14$ & 5.21 \\
\hline & $\mathrm{Bw}$ & $14-29$ & 1.89 \\
\hline & Cox & $29-41$ & 0.84 \\
\hline & $\mathrm{Cu}$ & $41+$ & 0.84 \\
\hline \multirow{4}{*}{ V9 } & $\mathrm{Ah}$ & $0-12$ & 6.79 \\
\hline & $\mathrm{Bw}$ & $12-22$ & 1.89 \\
\hline & Cox & $22-60$ & 1.30 \\
\hline & $\mathrm{D}+$ & $60+$ & \\
\hline
\end{tabular}

ultramafic rocks originating from the oceanic lithosphere, lithologies strongly deformed and metamorphosed under eclogitic-facies conditions (Schwartz et al., 2000).

The lower Guil Valley (Fig. 1C) crosscuts the Briançonnais anti-formal nappes stack (Tricart, 1984; Tricart et al., 2003), which contains the pre-, syn- and post-rift Tethyan sediments sourced from the stretched distal margin. The lithologies are mostly composed of Triassic carbonates, with additions of Permian-Triassic rhyolites and quartzites. This stack of cover nappes, shortened during the Oligocene, gives a present-day alpine fan-shaped structure, metamorphosed under greenschist facies conditions (Lanari et al., 2014) and modified by glaciation. Along the Guil River the landscape is marked by a magnificent deep gorge (Combe du Queyras) formed partly by the immense release of meltwater as the Guil Glacier retreated to higher elevation. These various lithologies observed in the upper Guil basin provide the resident sediment affected by massive heating from a suspected cosmic airburst across the whole of the valley, afterward dispersed into evolving paleosols (Mahaney et al., 2013b). It is within this diverse lithology that sediment in an early weathering stage was subjected to hypothesized intense heat and pressure

\section{MATERIALS AND METHODS}

Soil and paleosols were described following Birkeland (1999), NSSC (1995) and Canada Soil Survey Committee (CSSC) (1998). Specific soil/paleosol horizon terminology follows Birkeland (1999) and Hodgson (1976). Soil/paleosol descriptions follow standard protocol established by the NSSC (1995). The 'Cox' horizon designation, as defined by Birkeland (1999), highlights $\mathrm{C}$ horizons with detectable levels of secondary Fe hydroxides and oxides, whereas ' $\mathrm{Cu}$ ' refers to unweathered parent material (Hodgson, 1976). The 'Ah' horizon designation is used where sufficient color strength indicates appreciable humus (Canada Soil Survey Comm., 1998). Soil colors were assigned using Oyama and Takehara's (1970) soil color chips (equivalent to Munsell color sheets). Approximately 200-300 g wt. of single samples was collected from individual soil horizons for particle size, clay mineral, and geochemical analyses.

Sediment samples were air dried and treated with $30 \%$ $\mathrm{H}_{2} \mathrm{O}_{2}$ to oxidize organic material. The samples were then wet sieved, and the $<63 \mu \mathrm{m}$ fraction subjected to analysis by hydrometer (Day, 1965), the sand splits retained for SEM/EDS analysis. Particle grade sizes are based on the Wentworth Scale with the exception of the clay/silt boundary at $2 \mu \mathrm{m}$ which follows the U.S.D.A. Organic carbon was determined following the methods of Walkley and Black, (1934). Scanning electron microscopic (SEM) image analysis and chemical identification follow Mahaney (2002). Rind identification and measurement follows Mahaney et al. (2013a, b). Samples and methods used for metagenomic analysis are described in Mahaney et al. (2013b, 2016a).

\section{RESULTS}

\section{Guil/Po Catchments}

The total area impacted by the airburst/impact that produced the black mat in the Western Alps of France and Italy is unknown. Only the area between the upper Guil (Sites = G; Fig. 1A) and Upper Po (Sites = V; Fig. 1B) catchments have been surveyed to date comprising some $15-18 \mathrm{~km}^{2}$, the range in elevation stretching upward from $2400 \mathrm{~m}$ in France and $2000 \mathrm{~m}$ in Italy, to the Col de la Traversette (3000 $\mathrm{m}$ asl). Both the weathering rinds and thin soils impacted by the airburst/impact, existing today as paleosols (Fig. 2A, B); and Fig. 3 (that shows the full chronosequence), are included in this report; bedrock analyses are set aside for later release once the full extent of the sites is completed. All sites outlined below have been thoroughly analyzed for soil profile description, soil mineralogy and chemistry, with various details reported elsewhere (Mahaney and Keiser, 2013; Mahaney et al., 2013c, 2016a). In the main, the mid-LG paleosols contain pebble size clasts in the upper Ah horizons from which samples have been collected for rind analysis (Mahaney et al., 2016b), the rinds carrying various archives of the airburst/impact, first recorded by Mahaney and Keiser (2013). These rinds contain melted quartz, glassy carbon 
Table 2. REEs, Pt, Pd and Pt/Pd ratios ${ }^{\mathrm{a}}$ in cosmically-impacted Late Glacial and YD paleosols, Guil River catchment, Western Alps.

\begin{tabular}{|c|c|c|c|c|c|c|c|c|c|c|c|c|c|}
\hline \multirow{2}{*}{ Site } & \multirow{2}{*}{ Horizon } & $\mathrm{La}$ & $\mathrm{Ce}$ & $\mathrm{Nd}$ & Sm & $\mathrm{Eu}$ & $\mathrm{Tb}$ & $\mathrm{Yb}$ & $\mathrm{Lu}$ & Th & $\mathrm{Pt}$ & $\mathrm{Pd}$ & $\mathrm{Pt} / \mathrm{Pd}$ \\
\hline & & ppm & ppm & $\mathrm{ppm}$ & ppm & $\mathrm{ppm}$ & $\mathrm{ppm}$ & $\mathrm{ppm}$ & ppm & $\mathrm{ppm}$ & $\mathrm{ppb}$ & $\mathrm{ppb}$ & \\
\hline \multirow{4}{*}{ G3 } & $\mathrm{Ah}$ & 14.1 & 36.0 & 26.0 & 4.9 & 2.2 & 1.9 & 2.3 & 0.11 & 3.5 & 1.3 & 1.3 & 1.0 \\
\hline & $\mathrm{Bw}$ & 9.9 & 26.0 & 18.0 & 5.0 & 2.1 & 0.5 & 2.5 & 0.10 & 2.3 & 2.2 & 0.6 & 3.7 \\
\hline & Cox & 7.7 & 25.0 & 19.0 & 4.6 & 1.8 & 0.5 & 2.5 & 0.11 & 1.1 & 1.2 & 0.6 & 2.0 \\
\hline & $\mathrm{Cu}$ & 5.4 & 23.0 & 9.0 & 4.4 & 1.9 & 1.3 & 2.5 & 0.12 & $<0.5$ & - & - & - \\
\hline \multirow{4}{*}{ G3A } & $\mathrm{Ah}$ & 15.6 & 35.0 & $<5$ & 3.4 & 1.0 & $<0.5$ & 2.2 & 0.39 & 3.9 & 2.1 & 0.9 & 2.3 \\
\hline & $\mathrm{Bw}$ & 9.1 & 28.0 & 15.0 & 3.8 & 1.0 & $<0.5$ & 2.8 & 0.43 & 1.6 & $<0.5$ & 0.7 & 0.7 \\
\hline & Cox & 9.9 & 31.0 & 8.0 & 4.0 & 0.9 & $<0.5$ & 3.1 & 0.43 & 2.5 & $<0.5$ & 0.5 & 1.0 \\
\hline & $\mathrm{Cu}$ & 8.0 & 27.0 & 10.0 & 4.0 & 1.2 & $<0.5$ & 3.1 & 0.54 & 1.5 & $<0.5$ & $<0.5$ & 1.0 \\
\hline \multirow{3}{*}{ G9 } & $\mathrm{Ah}$ & 10.8 & 22.0 & 12.0 & 3.2 & 1.2 & $<0.5$ & 2.4 & 0.26 & 2.9 & 2.2 & 0.7 & 3.1 \\
\hline & $\mathrm{Bw}$ & 9.2 & 22.0 & 14.0 & 3.6 & 1.0 & 1.2 & 3.2 & 0.33 & 1.6 & 2.4 & 0.7 & 3.4 \\
\hline & Cox & 8.1 & 20.0 & 12.0 & 3.6 & 1.6 & 0.9 & 3.3 & 0.33 & 1.3 & 1.4 & 0.7 & 2.0 \\
\hline \multirow{4}{*}{ G11 } & $\mathrm{Ah}$ & 13.6 & 31.0 & 16.0 & 4.0 & 1.0 & $<0.5$ & 2.5 & 0.51 & 4.3 & $<0.5$ & 0.6 & 0.8 \\
\hline & $\mathrm{Bw}$ & 12.4 & 32.0 & 8.0 & 4.3 & 1.1 & $<0.5$ & 3.4 & 0.49 & 2.4 & 15.6 & 0.6 & 26 \\
\hline & Cox & 8,8 & 20.0 & 12.0 & 3.9 & $1.1^{`}$ & 0.7 & 3.1 & 0.43 & 1.6 & $<0.5$ & 0.6 & 0.8 \\
\hline & $\mathrm{Cu}$ & 5.7 & 23.0 & 9.0 & 3.9 & 1.3 & 0.7 & 3.3 & 0.47 & 1.0 & $<0.5$ & $<0.5$ & 1.0 \\
\hline \multirow{4}{*}{ V9 } & $\mathrm{Ah}$ & 12 & 82 & 14 & 3.2 & 0.7 & $<0.5$ & 2.6 & 0.35 & 2.8 & - & - & - \\
\hline & $\mathrm{Bw}$ & 13.8 & 31 & 16 & 3.5 & 1.1 & 0.9 & 2.4 & 0.26 & 3.6 & 1.8 & 0.9 & 2.0 \\
\hline & Cox & 11.7 & 24 & 12 & 3.4 & 0.9 & 0.6 & 3 & 0.33 & 3.2 & 7.2 & 0.9 & 8.0 \\
\hline & $\mathrm{D}+$ & & & & & & & & & & & & \\
\hline Crustal & Average $^{\mathrm{b}}$ & 37.1 & 63.7 & 27.0 & 4.7 & 1.0 & 0.6 & 2.0 & 0.3 & 10.0 & 0.5 & 0.5 & - \\
\hline
\end{tabular}

a not analyzed; ${ }^{b}$ Rudnick and Gao, 2005.

Table 3. REEs in post- and pre-LIA soils, Guil and Po river valleys, Mt. Viso Area of France and Italy.

\begin{tabular}{|c|c|c|c|c|c|c|c|c|c|c|c|c|c|c|}
\hline Site & Horizon & Depth $(\mathrm{cm})$ & $\mathrm{La}$ & $\mathrm{Ce}$ & $\mathrm{Nd}$ & $\mathrm{Sm}$ & $\mathrm{Eu}$ & $\mathrm{Tb}$ & $\mathrm{Yb}$ & $\mathrm{Lu}$ & Th & Pt & $\mathrm{Pd}$ & $\mathrm{Pt} / \mathrm{Pd}$ \\
\hline G6 & $\mathrm{Cu}$ & $0-10$ & 13.1 & 29 & $<5$ & 2.8 & 0.3 & $<0.5$ & 2.1 & 0.17 & 4.9 & - & - & - \\
\hline G8 & Cox & $0-15$ & 5.9 & 25 & $<5$ & 3.8 & 1.3 & $<0.5$ & 3.5 & 0.3 & 0.9 & - & - & - \\
\hline G10 & $\mathrm{C}$ & $0-18$ & 9 & 28 & $<5$ & 4 & 0.9 & $<0.5$ & 3.5 & 0.23 & 2.1 & - & - & - \\
\hline \multirow{3}{*}{ G7 } & $\mathrm{Ah}$ & $0-4$ & 11.6 & 29 & 17 & 3.1 & 0.8 & 1.3 & 2.5 & 0.2 & 3.0 & - & - & - \\
\hline & Clox & $4-15$ & 8.1 & 18 & 8 & 2.2 & 0.6 & $<0.5$ & 1.8 & 0.21 & 2.4 & - & - & - \\
\hline & $\mathrm{C} 2 \mathrm{ox}$ & $15-25$ & 6.2 & 19 & $<5$ & 2.8 & 0.9 & $<0.5$ & 2.3 & 0.24 & 2.1 & - & - & - \\
\hline \multirow{3}{*}{ V8 } & $\mathrm{Ah}$ & $0-10$ & 6.7 & 24 & $<5$ & 3.6 & 0.7 & $<0.5$ & 2.9 & 0.24 & $<0.2$ & - & - & - \\
\hline & $\mathrm{C}$ & $10-22$ & 5.1 & 18 & $<5$ & 4.1 & 1.8 & $<0.5$ & 3.6 & 0.34 & $<0.2$ & - & - & - \\
\hline & $\mathrm{Cu}$ & $22+$ & 4.7 & 15 & $<5$ & 4.1 & 1.4 & $<0.5$ & 3.6 & 0.36 & $<0.2$ & - & - & - \\
\hline Crustal & Average $^{\mathrm{a}}$ & & 37.1 & 63.7 & 27.0 & 4.7 & 1.0 & 0.6 & 2.0 & 0.3 & 10.0 & & & \\
\hline
\end{tabular}

${ }^{a}$ from Rudnick and Gao (2005).

spherules, opaque carbon clusters welded onto grains of country rock origin, Fe spherules and elevated variable concentrations of $\mathrm{Co}, \mathrm{Cu}, \mathrm{Ni}$ and REEs, mostly elevated above crustal averages (Rudnick and Gao, 2005). A representative sample, shown in Fig. 4, is of a typical rind with a thickness variation of $3-0 \mathrm{~mm}$, the thicker rind with a reddish hue, near 7.5YR 4/6, possibly due to strong hematization resulting from the airburst/impact, as reported at other YDB impact sites (e.g., Firestone et al., 2007).

Similar concentrations of chemical elements from local sources plus minor trace concentrations of elements that could have a cosmic source, such as Pt, are also found in paleosols associated with the analyzed rinds. In fact, local paleosol horizons contain significant concentrations of $\mathrm{Pt}$, such that $\mathrm{Pt} / \mathrm{Pd}$ ratios rival that of meteor impacts, and the $\mathrm{Pt}$ is at concentrations much higher than that found in the
YDB impact layer of the Greenland Ice Sheet by Petaev et al. (2013). SEM imagery at every site shows a multitude of welded grains (Fig. 5A, B), of variable lithology, sometimes as discrete entities and/or welded into airburst forms documented at other sites or as sand/silt spherules (Figs. 6A, $\mathrm{B}, 7 \mathrm{~A}, \mathrm{~B}$ ) of varying porosity, some poorly formed, others melted to near micron size (Fig. 8A, B) with grains tightly welded (Fig. 9). Large grains of medium silt to fine sand grade size comprise these large welded clusters with EDS analysis showing mostly olivine, pyroxene, amphibole and Ca-plagioclase signatures correlated to the country rock. Grains of fine silt and near clay size sediment (Fig. 8A, B) often carry an impact-related signature with elevated concentrations of $\mathrm{Co}, \mathrm{Cu}$ and $\mathrm{Sn}$.

Energy dispersive spectrometry (EDS) analysis typically depicts a similar chemistry across grains and even in 

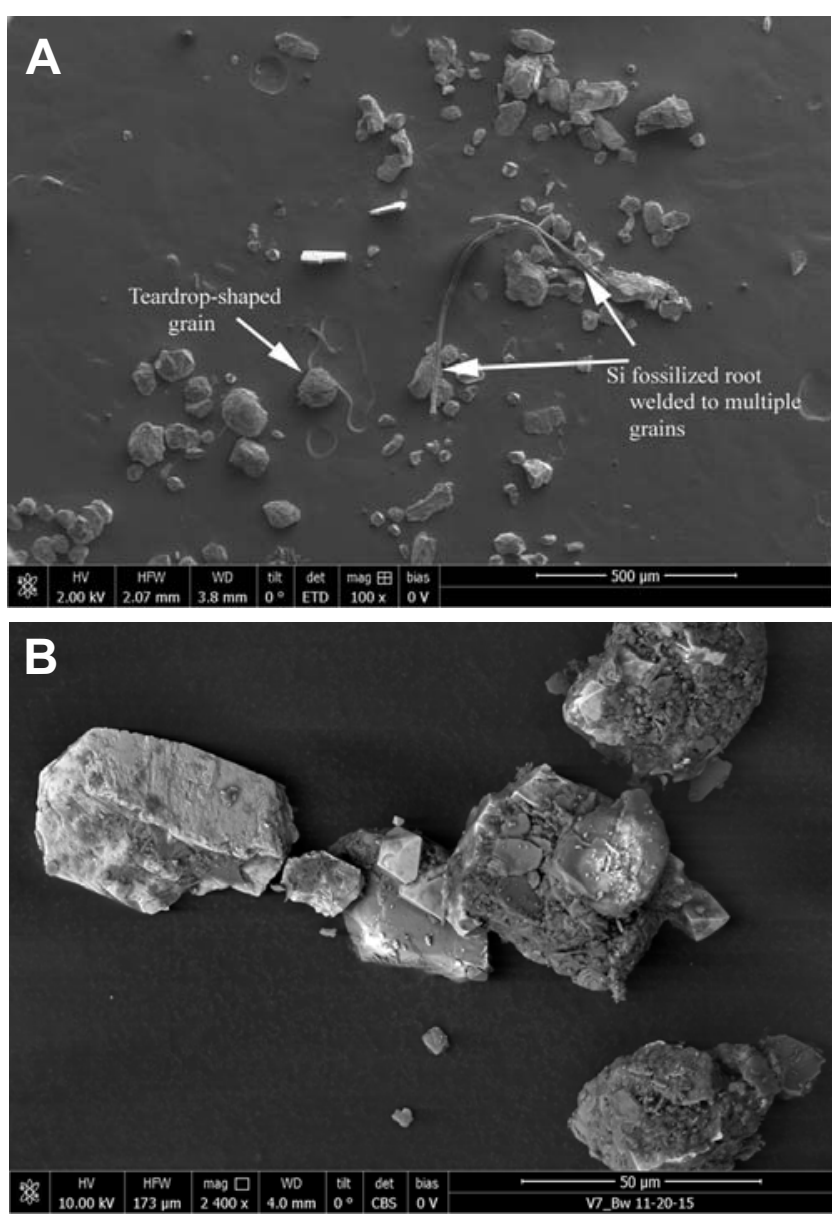

Fig. 5. A - General frame of grains in G11-Bw, some welded together and all of silt and very fine sand grain size; B - General frame of grains in $\mathrm{V} 7-\mathrm{Bw}$, ranging from silt to near middle sand grade size and welded grains, with one large spherule of very fine sand. These grains are typical of the population of minerals recovered from all mid-LG sites in the upper Po and Guil catchments.

the spherule form in sizes up to a $20-\mu \mathrm{m}$ diameter with a few even larger (Fig. 10A). Si dominates over Al (Fig. 10B), often with both elements in variable concentrations, given the pyroxene-dominated sediment. Occasionally, chlorine appears with Al suggesting a cosmic origin with $\mathrm{Cl}$ acting as probable ion sites in aluminosilicate glass (Stebbins and $\mathrm{Du}, 2002)$. Sulphur is present in small concentrations. Carbon is high throughout and sometimes quite variable from near trace to the dominant element, varying according to the percentage of organics present at time of impact/ airburst. Some samples, as indicated, were run without coating so the carbon is real. Sodium, $\mathrm{K}, \mathrm{Mg}$ and Fe are common in small concentrations.

Affected sands and silts seen under the light microscope and SEM (Fig. 5A, B) show variable degrees of angularity to roundness, the former the product of fragmentation, the latter presumably the product of melting. Many grains of variable angularity are seen welded to round grains, suggesting that since different lithologies melt at different temperatures, grains with lower melting temperatures are the first to deform and become attached to a still intact un- melted fragment. As shown here in Fig. 5A, B, light toned Fe rich grains are commonly deformed and many smaller fragments are welded onto fossilized and hematized plant roots. Grains in Fig. 5B are clustered in a welded form with a large spherule, the exact composition of which is unknown.

Airburst grains, often welded into streamlined shapes (Fig. 6A) and/or sand spherule forms (Fig. 7A), are composed of grain clusters of mainly country rock. The welded collage of grains in Fig. 6A is composed of larger grains that appear to have greater porosity, whereas the spherule (Fig. 7A) contains grains with smaller diameters and probably less porosity. Both grain assemblages contain about the same chemistry (Figs. 6B, 7B) over the analyzed areas, all representative of the chemistry of the local source rock. Smaller fragments, such as the near clay size grain in Fig. 8A, with small bulbous protrusions, depict a melted/quenched morphology similar to that described by Andronikov et al., 2016a) suggestive of an airburst origin. The chemistry of this grain and its coating, Ni and $\mathrm{Sn}$ in particular, is suggestive of a cosmic impact (De Laeter and Jeffrey, 1965), with a high content of Fe supporting an impact interpretation, although no crater has been conclusively identified yet.

Probably the most convincing evidence of a cosmic event comes from shock-melted minerals (Mahaney, 2002), as shown in Fig. 11 from low magnification to higher magnification, a series of ever increasing resolution of surface area on a single grain with accompanying EDS chemistry. The chemistry clearly indicates this grain is Fe-rich, presumably magnetite or hematite, with the presence of minor Si being insufficient to argue for chamosite, although chlorite is frequently identified in the clay fraction of local paleosols (Mahaney et al., 2016a). The degree of melting is strong, but not as advanced as in other ejecta, as from the Yucatan impact of $65 \mathrm{Ma}$ (Mahaney, 2002; Fig. 11C), where quartz suffered severe melting with annealed smaller silt size grains in cavities. Such collections of annealed silt-size grains are present in Fig. 11B but not with the frequency of Yucatan grains recovered from Clear Creek, Colorado and discussed by Mahaney (2002).

The YD moraines in the Guil catchment, shown on Fig. 1A, lie just beyond the inner mid-LG moraine across much of the valley the latter deposit flattened somewhat by meltwater release off the YD front. To the south, near site G9 (Fig. 1A), the younger YD moraine overlies the older mid-LG deposit, the stratigraphic succession offering a clear relative age assessment. The YD deposits are shown in Fig. 1 (Mahaney et al., 2016a) and carry a clastic load similar to what has been described in the mid-LG deposits, with the one exception that large clasts (principally boulders and large cobbles) lie embedded in the distal margins of the moraine with a-axis orientations of $\sim 270^{\circ} \pm 15^{\circ}$ suggestive of a push moraine origin correlating well with a YD resurgence of ice. Rinds collected at several sites depict weathering thicknesses of $\sim 2-3 \mathrm{~mm}$ well within the range seen on rinds collected from the surface of mid-LG deposits (Mahaney and Keiser, 2013), although lacking traces of 

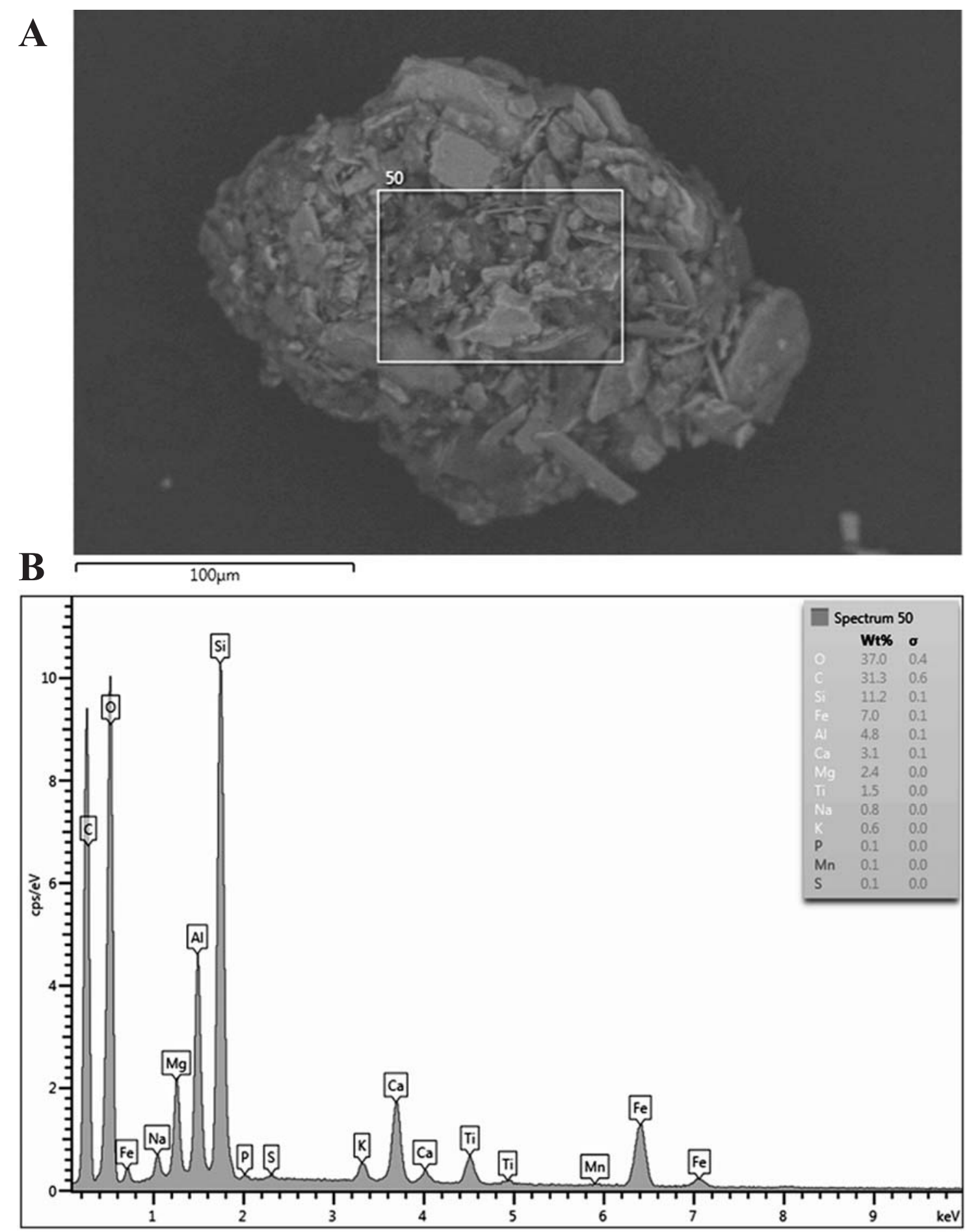

Fig. 6. A - Airburst grain from G11-Bw composed of welded minerals of variable composition, all sourced from local metabasalt and with high carbon content; B - The sample was analyzed without conductive coating so the carbon content is real.

melted and highly fractured outer rind areas $(\sim 700 \mathrm{~nm})$ as detailed by Mahaney and Keiser (2013) and Mahaney et al. (2016b). Paleosols within the YD group carry similar depth/horizonation to the older mid-LG profiles and classify into the same soil order as the older paleosols. Analysis of the sand fraction of the bulk samples collected from YD profiles yields grains with similar weathering features as are present on clasts within the mid-LG profiles (Fig. 12), but lack the multitudinous grains showing melted, welded airburst characteristics found on grains in the older profiles. While the soil morphogenetic characteristics of the two sets of paleosols - mid-LG to YD - are similar, only the older group of profiles carry the properties consistent with an impact or airburst. 


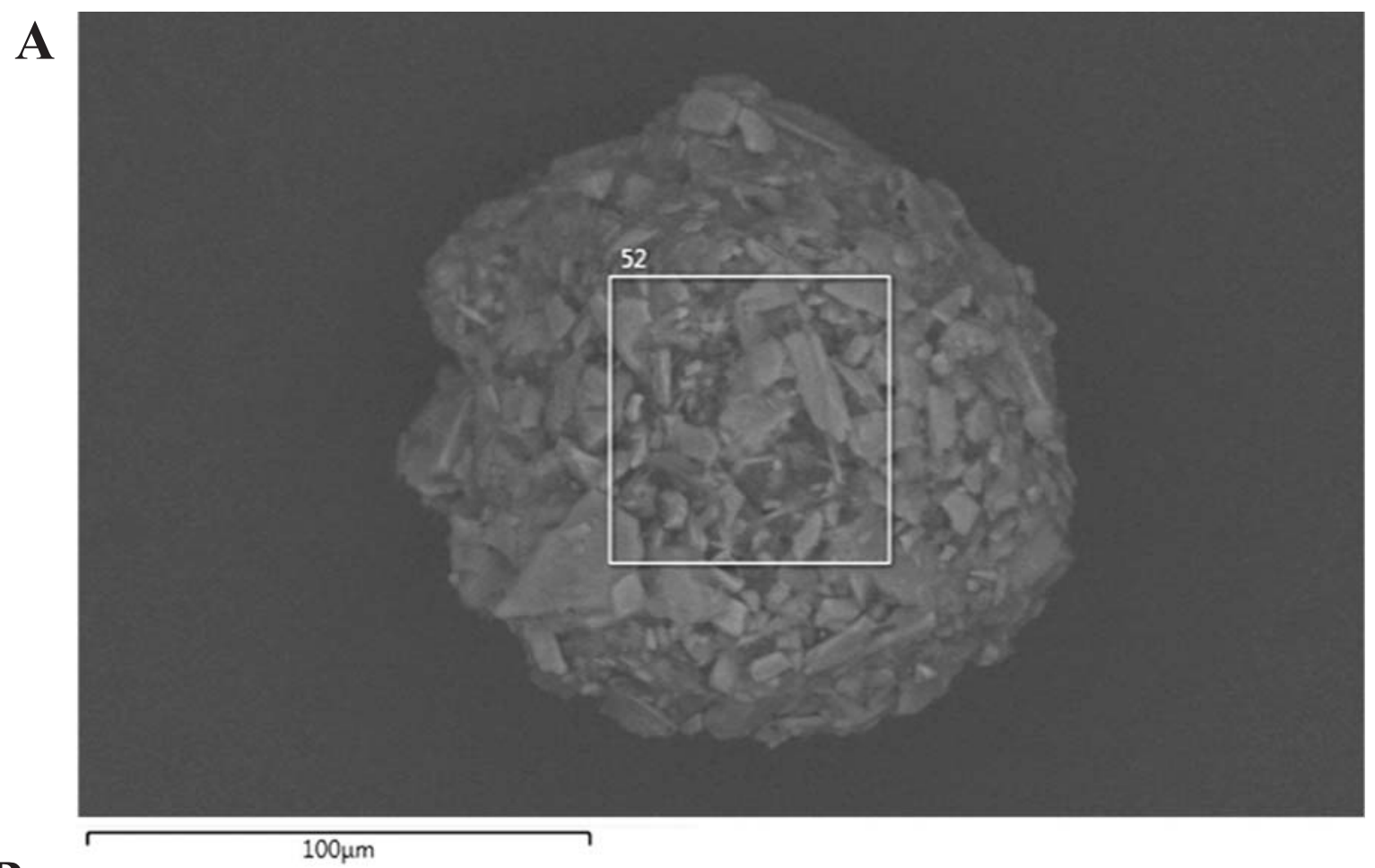

B

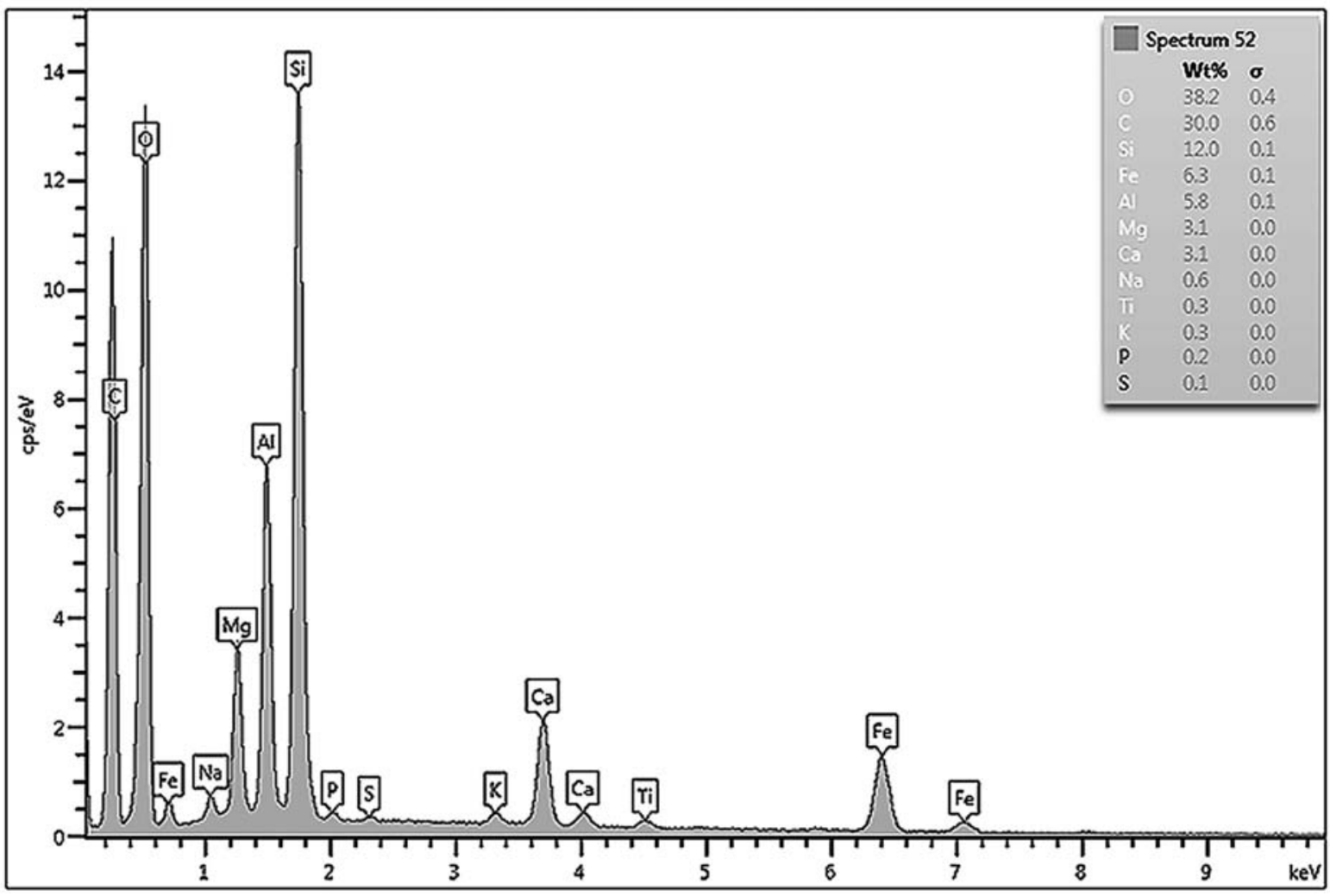

Fig. 7. A - Spherule from G11-Bw with near elliptical form; B - EDS indicates a similar composition to the compacted grains in Fig. 6.

\section{Soil/Paleosol Physico-Chemical Properties}

The LIA and post-LIA soils are all Entisols with $\mathrm{C}$ or Cox profiles or fresh sediment $(\mathrm{Cu})$, with identification made on the basis of color and particle size. The fresh sediment of post-LIA age ( $\mathrm{Cu}$ horizon) carries $2.5 \mathrm{Y} \mathrm{5/2}$, $5 / 4$ colors with coarse sandy texture, loose to very friable consistence with non-plastic and non-sticky properties. The 


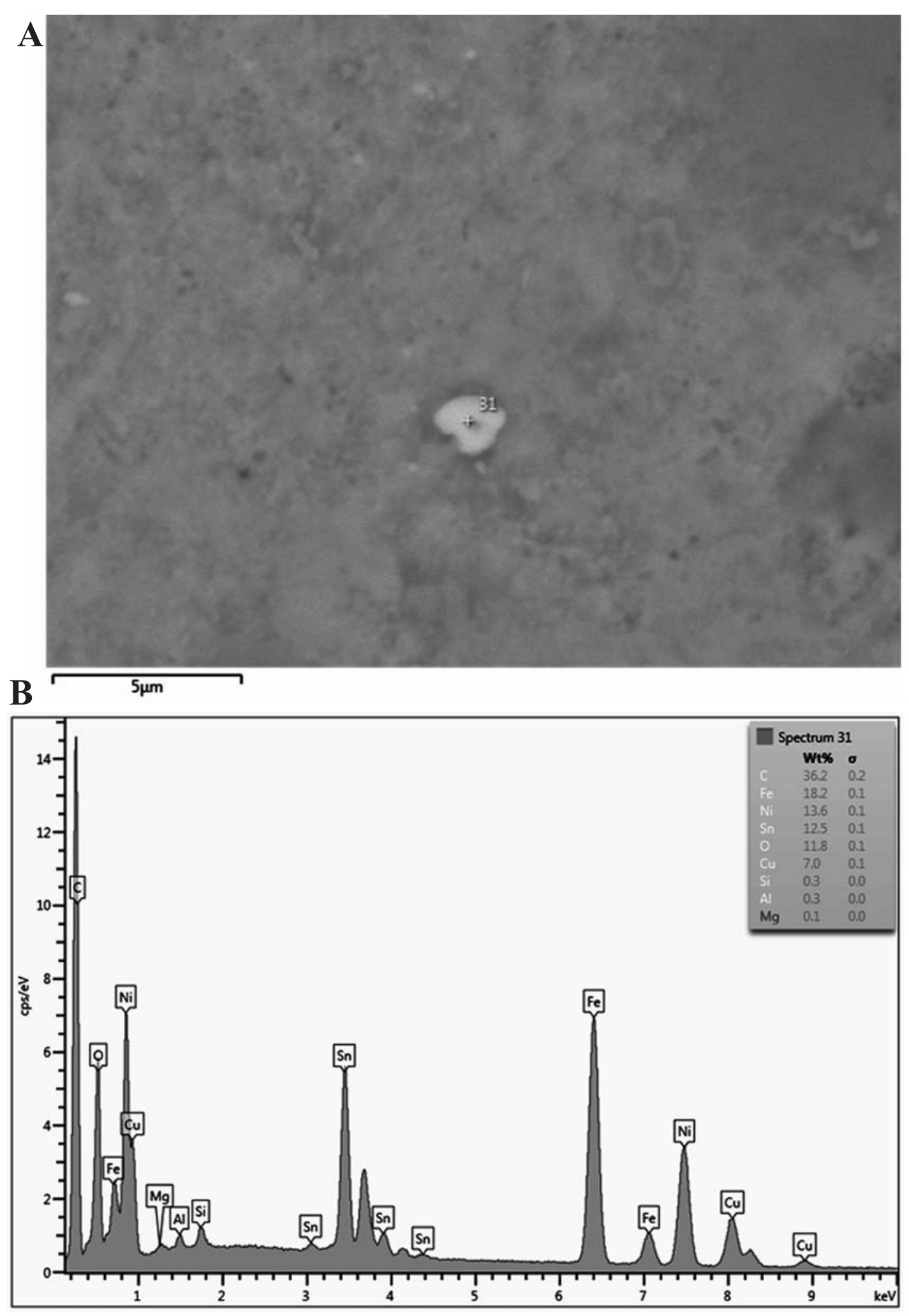

Fig. 8. A - Near clay size grain from $\mathrm{G} 11-\mathrm{Bw}$; B - allochthonous elements, principally, $\mathrm{Cu}, \mathrm{Ni}$ and $\mathrm{Sn}$ are indicated in the spectrum.

LIA profiles of partially weathered sediment carries $\mathrm{C} /$ $\mathrm{Cu} / \mathrm{D}$ or $\mathrm{Cox} / \mathrm{Cu} / \mathrm{D}$ profiles with $10 \mathrm{YR} 5 / 4-5 / 6$ colors in the weathered horizon, with sandy loam textures, no structure, and very friable consistence, non-plastic and non- sticky characteristics. The pre-LIA profile, considered to be of middle Neoglacial age ( 2-3 ka) based on comparison with similar age soils near Mt. Blanc, $100 \mathrm{~km}$ to the north (Mahaney, 1991), carries an Ah horizon, lacks a B horizon, 
with multiple $\mathrm{C}$ horizons, all showing evidence of oxide/ hydroxide release. Stronger colors of $10 \mathrm{YR} 2 / 2$ in the Ah horizon and finer sandy loam textures throughout the profile (G7) are accompanied by granular soil structure in the soil epipedon (Ah horizon), structureless conditions below, variable very friable or friable consistence and non-plastic and non-sticky characteristics throughout. A similar but somewhat coarser textured profile exists in the upper Po catchment (V8), also considered to have a similar middle Neoglacial age, and carries an $\mathrm{Ah} / \mathrm{C} / \mathrm{Cu}$ profile with similar characteristics to $\mathrm{G} 7$.

It is on this physical-mineral base with seral vegetation development in a wet tundra that a heat release is presumed to have accompanied an airburst or impact, one that welded and deformed existing sediment to an extreme that matches other altered sediment attributed to the black mat event of $12.8 \mathrm{ka}$. Despite the lack of radiocarbon dates for the moraines in question, the stratigraphic situation of older mid-LG moraine overlain with younger, presumably YD moraine (see Fig. 1A for deposit identification), and with the younger deposit showing push moraine characteristics supports a YDB age for the welded/deformed sediment in the older unit. Since opaque carbon mats welded onto mineral grains and glassy carbon spherules are frequently cited as black mat airburst/impact products, the question of available terrestrial carbon at time of the cosmic event is of prime importance.

Within the LIA profiles, organic carbon (Table 1) ranges around $1 \%$ whereas with the older middle Neoglacial profiles organic carbon reaches to between 4.8 and $6.5 \%$ in the Ah horizons, decreasing normally with depth. Considering that organic carbon resident in profiles at the time of the airburst/impact was probably likely of a composition midway between the LIA and middle Neoglacial compositions reported here, it is most probable the Late Allerød soils probably carried $\sim 2 \%$ organic carbon at time of the airburst, some of which forms welded opaque carbon within weathering rinds (Mahaney and Keiser, 2013) on mid-LG deposit surfaces and on sand surfaces previously analyzed (Mahaney et al., 2013b). The remainder was probably instantly oxidized.

The older group of mid-LG and younger YD paleosols are Inceptisols with $\mathrm{Ah} / \mathrm{Bw} / \mathrm{Cox} / \mathrm{Cu}$ profiles that carry depths of $\sim 50 \mathrm{~cm}( \pm 10 \mathrm{~cm})$ with textures coarsening downward, colors of 10YR 2/1 in the Ah horizons, becoming more reddish with depth, becoming mottled in the mineralic $\mathrm{C}$ horizons, and grading to yellow $(2.5 \mathrm{Y} 5 / 4)$ in the parent materials ( $\mathrm{Cu}$ horizons). Structures are granular in the Ah group of horizons, becoming weak blocky in the Bw group, and massive below into the parent materials. Particle size ranges from silty sand in the surface to sandy silt or sandy loam at depth, Consistence is either friable to very friable in the Ah to friable and sometimes firm in the Bw, grading to loose in the $\mathrm{C}$ and $\mathrm{Cu}$ horizons. Only few horizons reach slightly sticky to slightly plastic properties at depth. These older mid-LG and younger YD paleosols carry variable organic carbon, concentrations varying from $\sim 3$ to $\sim 7 \%$, all concentrations controlled by microclimate and microto-

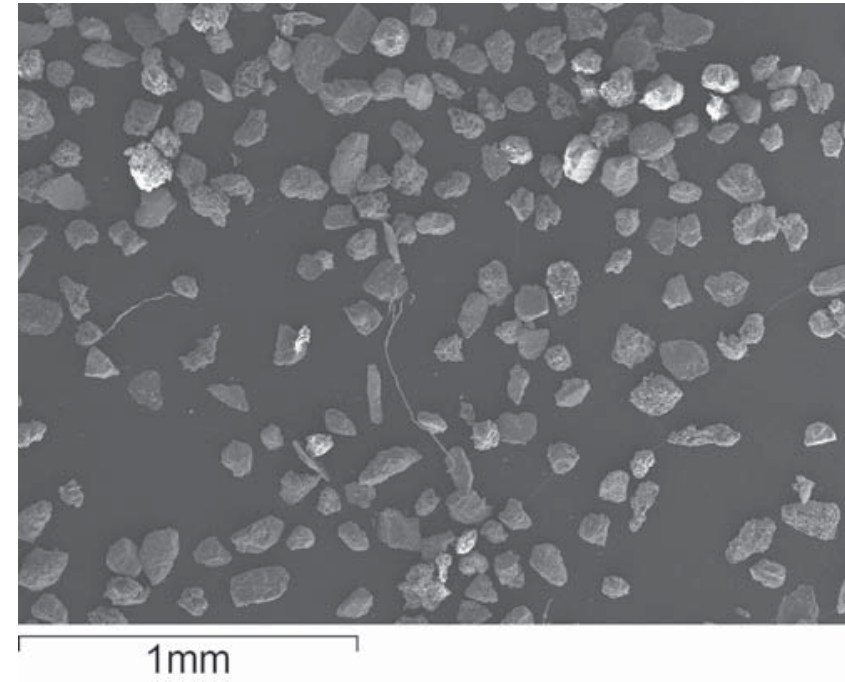

Fig. 9. General frame of grains in V9-Bw, some with light contrast indicating Fe compositions or coatings, others welded together.

pography. Because organic matter follows nitrogen and $\mathrm{pH}$, reaching asymptote levels by or before middle Neoglacial time $(\sim 2.5 \mathrm{kyr})$ it is probable that the levels in Table 1 represent concentrations of an organic carbon reservoir that developed since the airburst/impact of $12.8 \mathrm{ka}$.

Rare earth elements (REEs: La, Ce, Nd, Sm, Eu, Tb, Th, Pt and Pt) were evaluated at the mid-LG sites listed in Table 2-G3, G3A, G9, G11 and V9 - to test for the potential effects of the YDB impact event at this various localities. Several of these elements, especially the heavy REEs (Eu to $\mathrm{Tb}$ ) were found to be elevated above normal crustal abundance (Rudnick and Gao, 2005) throughout the mid-LG paleosol/deposit with occasional element concentrations below crustal average whereas within the lighter REEs only one sample in V9 had a higher concentration above average. The remaining elements elevated above crustal averages both in the mid-LG paleosol bodies and parent material (Cu horizons) are most likely coeval with the YD impact event and YD climate changes outlined above and in Mahaney et al. (2016a). A similar REE distribution is found within the YD profiles but with lower elemental concentrations, which suggest reworking of older mid-LG sediment into YD profiles. The same elemental abundances are also elevated in the impact layer at other YDB sites in three countries on two continents, including Blackwater Draw, New Mexico; Murray Springs, Arizona; Lake Hind, Manitoba, Canada; Lommel, Belgium; and Topper, South Carolina (Firestone et al., 2010) and Andronikov et al., 2016b). The causes of the enrichments are unclear, but may result from one or more of the following: a) normal sedimentary processes that lead to concentration of heavy minerals; b) aeolian influx of scavenged local terrestrial ejecta from the YDB impact/airburst event; and c) arrival of extraterrestrial material from a comet/asteroid vehicle explosion; and/or d) concentration of solutes from airburst/ impact-related acid rain. 

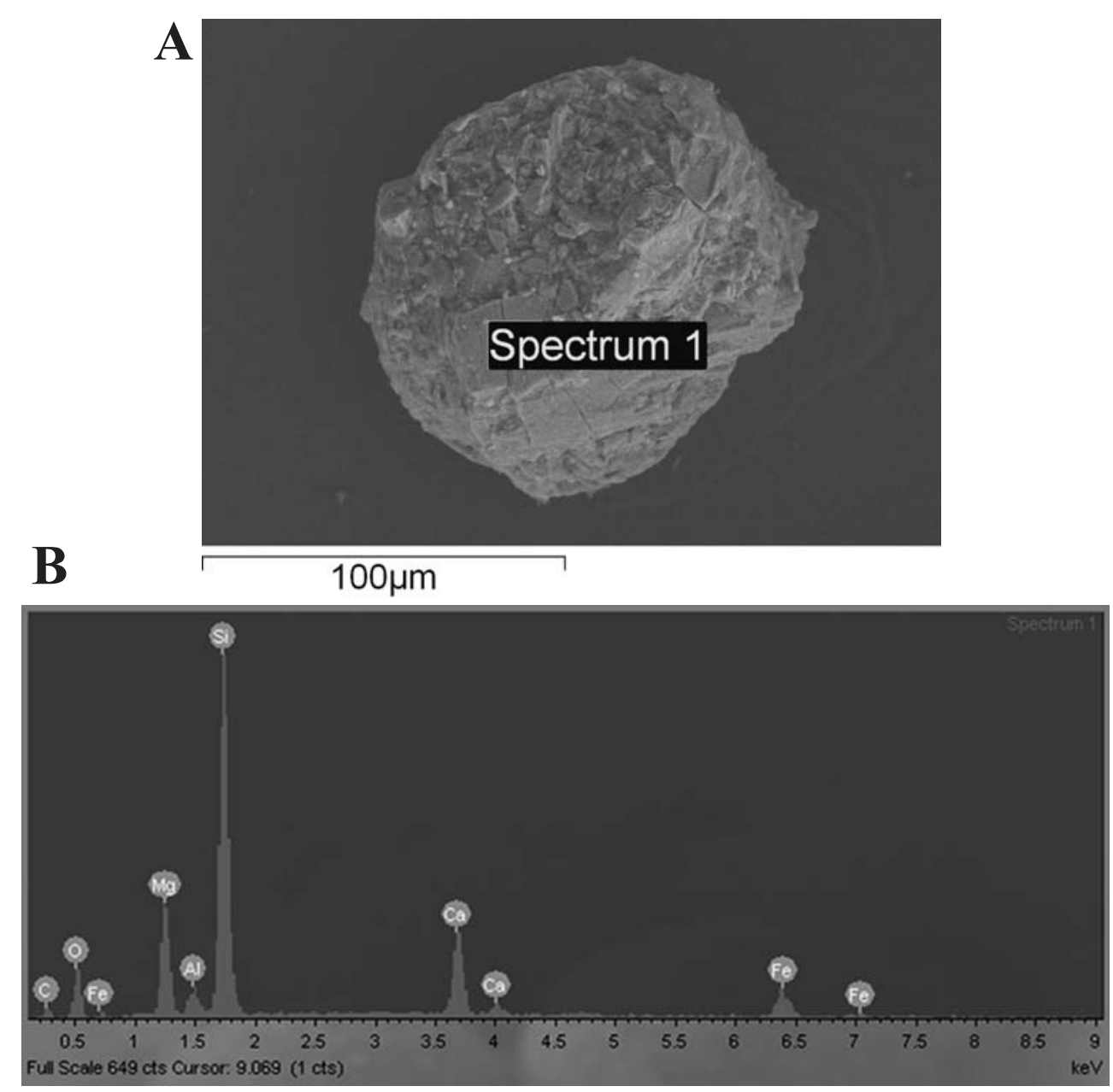

Fig. 10. A - Spherule-formed grain of variable composition with welded fragments in V9-Bw (see Mahaney et al., 2013d for section details); B - EDS spot analysis of one grain, amid the collective assemblage of welded grains, highlights a terrestrial composition of Si:Al = 9:1, with near equal ratios of $\mathrm{Ca}: \mathrm{Mg}$, with low $\mathrm{Fe}$ and lower $\mathrm{C}$, possibly augite but with low Al.

A selected group of younger soils dating from post-LIA, LIA and pre-LIA were sampled for REE and Th concentrations (Table 3) to compare with elemental distributions in the mid-LG group of paleosols discussed above in Table 2. Again the light REES are well below crustal averages with a detrital distribution of heavy REEs present particularly with $\mathrm{Yb}$ and $\mathrm{Lu}$ probably reworked from older deposits. Since these soils formed in deposits with ages well removed from the YDB, Pt and Pd metals were not analyzed.

\section{DISCUSSION}

\section{Comparison - Western Alps to Andes}

One unanswered question regarding various depictions of the YDB black mat event is what weathered/fresh sediment state existed at the time of the impact event (Fig. 3A, B). Since little information exists about sites in mountainous areas, we can only refer to the MUM7B site in the Andes (Mahaney et al., 2011b, 2013c) and the area around Mt. Viso in the Cottian Alps of France and Italy (Mahaney and Keiser,
2013; Mahaney et al., 2013b), the latter under discussion here. At MUM7B, the pre-impact sediment suffered mild diagenesis prior to the impact/airburst event, the alluvial/ lacustrine beds deposited prior to the event and a $20-\mathrm{cm}$ thick bed of outwash sand exhibited little weathering effects having been deposited in front of the retreating Mucuñuque Glacier (Mahaney et al., 2013c). Stream dynamics changed upward in the section where fine sands and gravels were impacted at the YDB, the affected black mat, a distinct black bed 2-3 cm thick, was covered by freshly deposited alluvium overrun by advancing Younger Dryas ice that reached a terminal position about $0.4 \mathrm{~km}$ down-valley where the youngest in a succession of stacked glacial deposits exists (Mahaney et al., 2010). Here, as at other sites, affected melted/welded sediment with characteristic airburst grains lies within a highly carbonized mass produced by biomass burning, sometimes mixed with cosmic sourced material. At some sites the affected sediment and carbonized material form separate subsets. In the Alps in the Guil-Po valleys the separation of carbonized and physically affected materials is seen only in weathering rinds (Mahaney and Keiser, 2013), mixed sediment relegated to Late Allerød paleosols described below. 

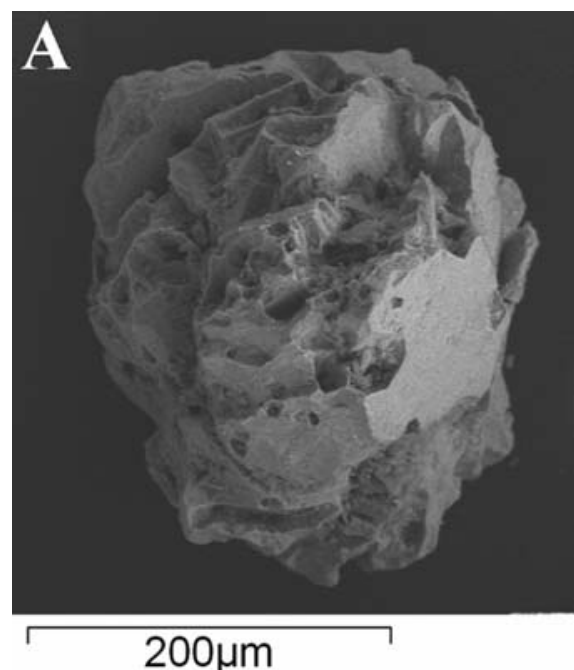
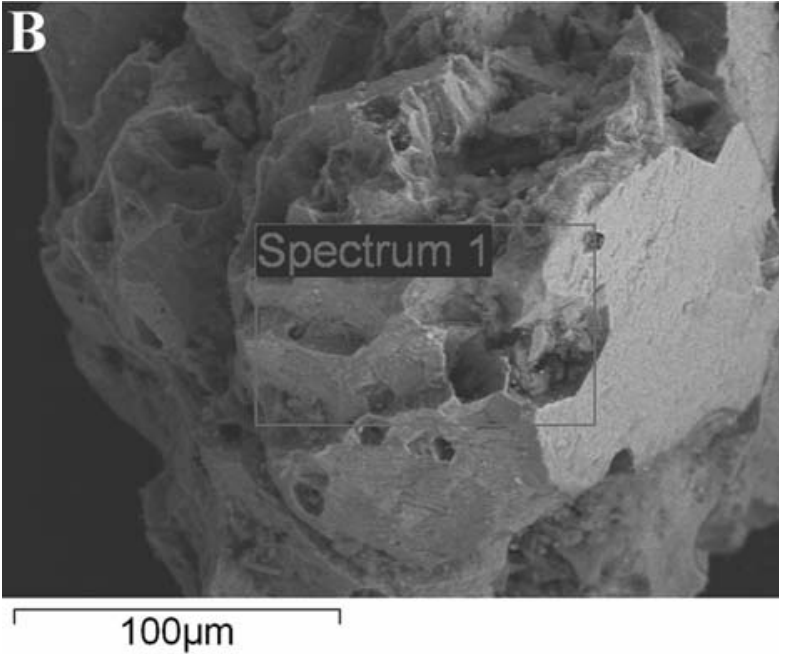

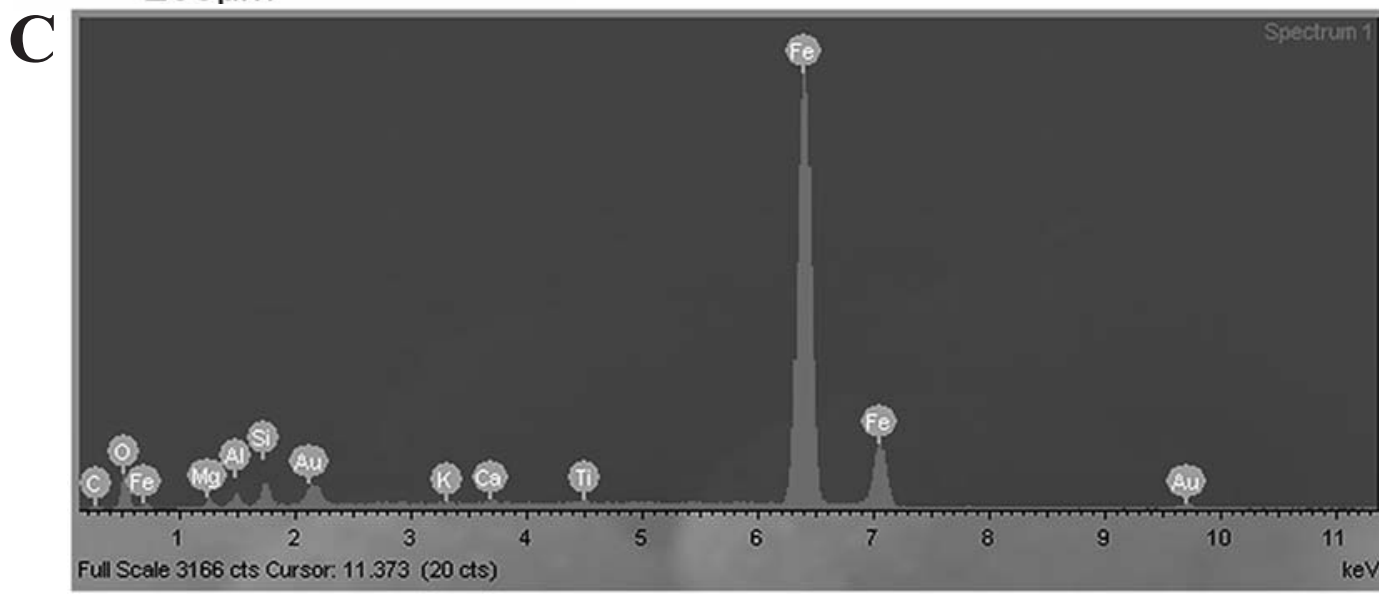

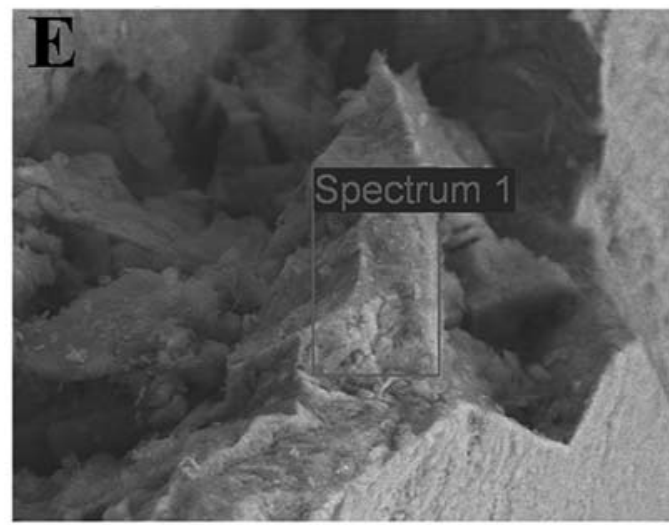

$40 \mu \mathrm{m}$

\section{D}

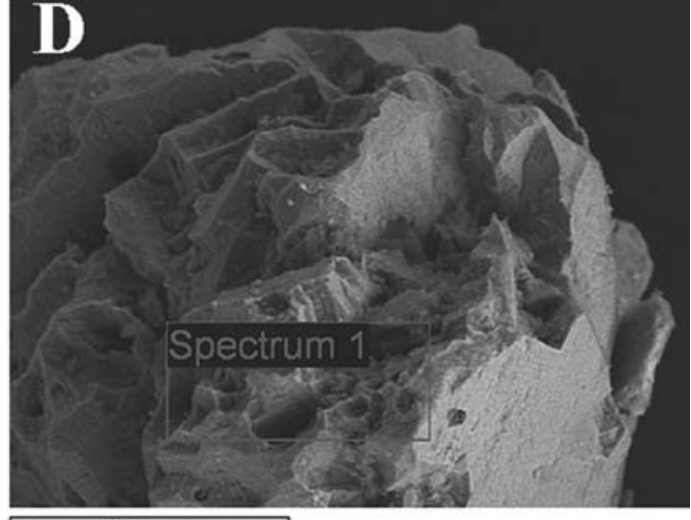

$100 \mu \mathrm{m}$

Fig. 11. A - Shock-melted Fe-rich grain in G3-Ah, possibly magnetite or chamosite; B - Enlargement of grain in A showing area of EDS analysis; $\mathrm{C}-\mathrm{EDS}$ analysis highlights high $\mathrm{Fe}$ and minor $\mathrm{Ti}$, $\mathrm{Ca}, \mathrm{K}, \mathrm{Mg}$. The $\mathrm{Au}$ is the conductive coating; D - Greater enlargement of the upper part of the grain in A; E - Still greater enlargement of upper part of the grain in A showing details of welded spindles of $\mathrm{Fe} ; \mathrm{F}$ - EDS chemistry similar to $\mathrm{C}$ with slightly higher Si and Al.

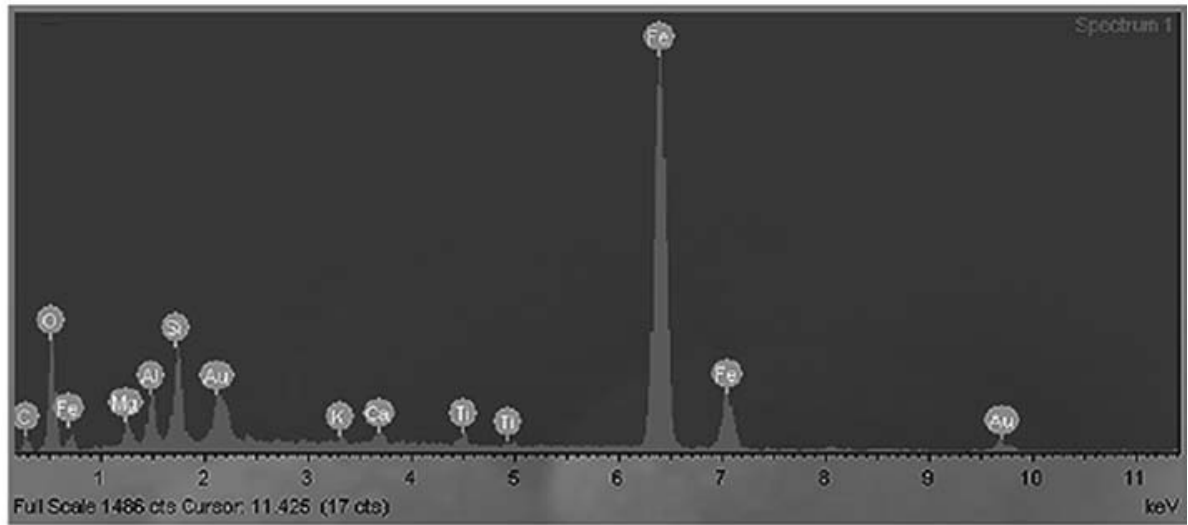




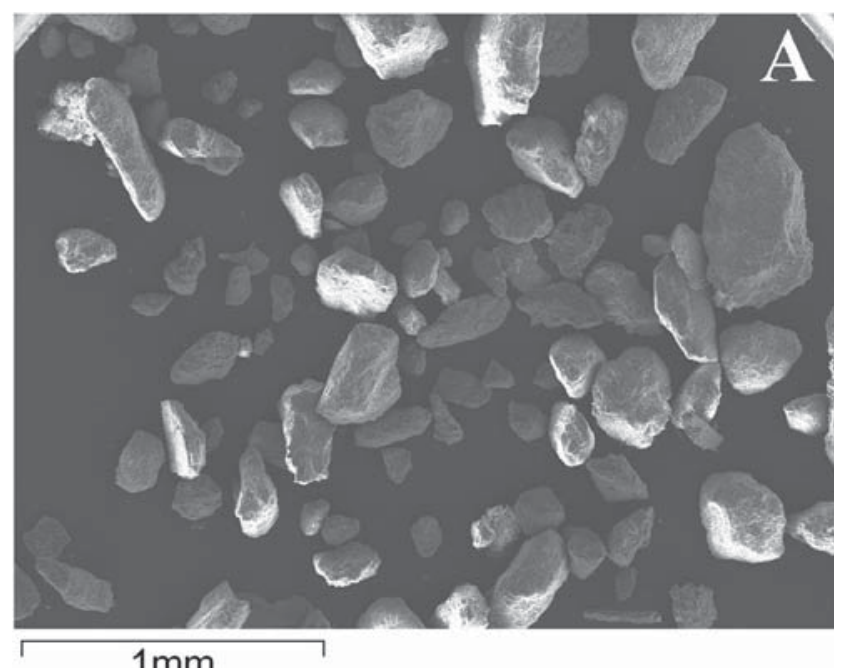

$1 \mathrm{~mm}$
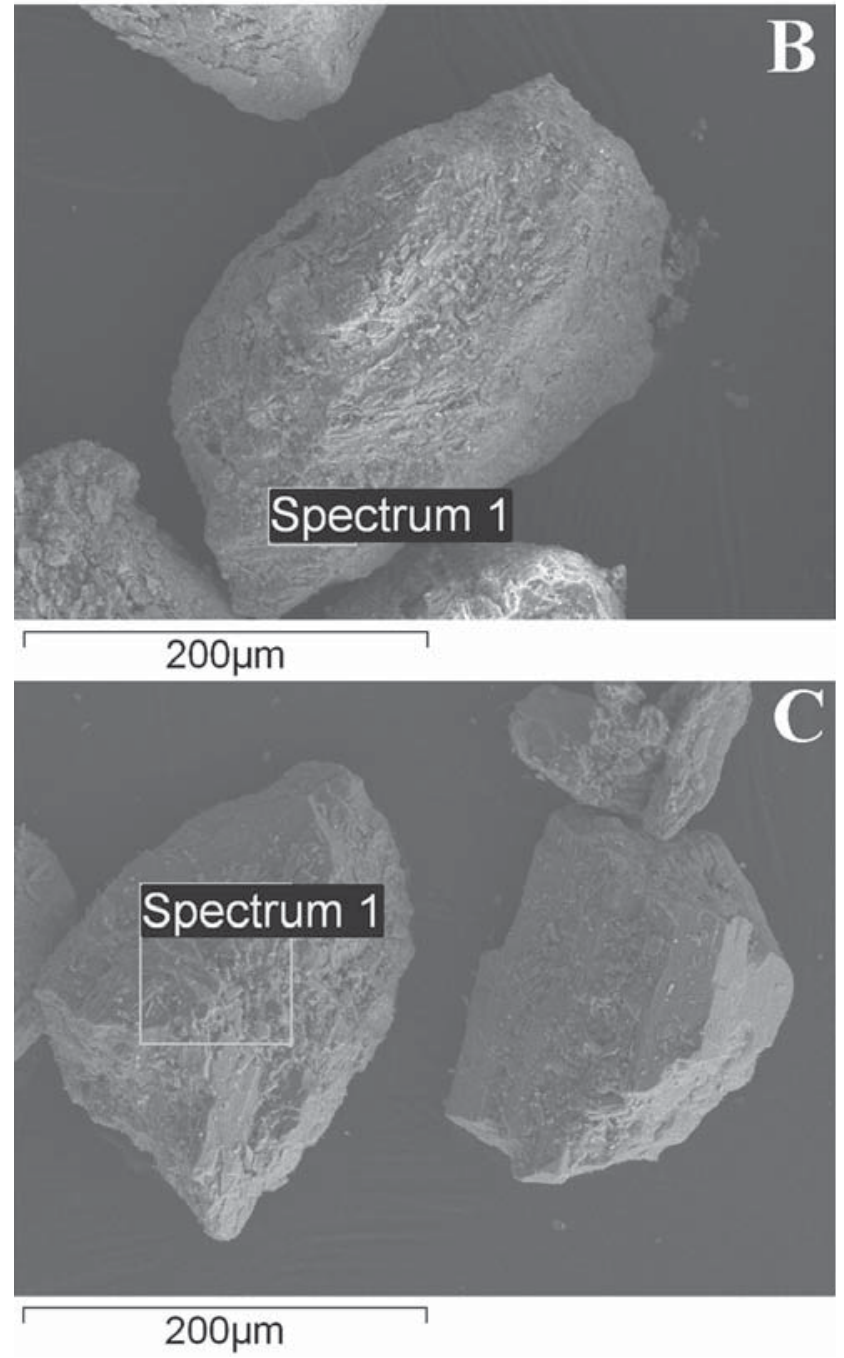

Fig. 12. Representative sands from the YD profiles un-affected by theorized cosmic airburst; A - Subangular to angular grains of the Cox horizon in the $\mathrm{G} 1$ paleosol; $\mathrm{B}$-Angular hornblende; $\mathrm{C}$-Angular pyroxene, possibly augite.

In contrast to the Andes site, retreating Würm ice in the Durance/Guil valleys reached to about $\sim 2400 \mathrm{~m}$ asl after building recessional moraines about $\sim 0.2 \mathrm{~km}$ apart between
2350 and $2400 \mathrm{~m}$ elevation (Fig. 3A), where the last stillstand moraine system in the main retreat phase was vacated by ice sometime before the YD. While age control here is tentative and based on other work in neighboring catchments, it is clear, given the lack of recessional moraines in the lower valley, that moraine deposited in the Late Allerød probably had properties similar to LIA deposits that exist in the Traversette Cirque today (Fig. 3B; location of the Traversette col in Fig. 1A), that is, coarse cobble/pebble sand texture, fresh sediment with little oxidation effects, porous enough to allow preservation of spores and growth of plants and with soils that may have had shallow $\mathrm{A} / \mathrm{C}$ / $\mathrm{Cu}$ or $\mathrm{C}(\mathrm{ox}) / \mathrm{Cu}$ profiles with thin horizons, total thickness $<20 \mathrm{~cm}$. In contrast, the landscape of today (Fig. 3E), 12.8 thousand yrs after the impact event, still contains coarse clastic sediment as well as $\sim 50 \%$ plant cover and a paleosol (Fig. 3F), similar to the profiles shown in Fig. 2. We may only conjecture what the surface looked like exactly when either a meteor exploded on surface or a comet fragment burst in the atmosphere overhead. However, from the evidence available, all surface material was affected by intense release of heat, energetic collision of material in the incoming body with the ground surface, possibly in ratios of 1:10, given that the majority of samples analyzed are of local provenance (Fig. 3C).

Scaling the recovered samples by size, cosmic connected grains are of inordinantly small diameter, mostly $<5$ $\mu \mathrm{m}$. Because the resulting carbon residue from the event is small, it is likely the surface vegetation at the time of the event was in the early stage of succession, and given that the retreating Allerød ice in the upper cirque was decanting huge amounts of meltwater into the moraines lower down, it is likely both the plant cover and wet surface suffered instant volatilization. Water evaporated into what must have been a low pressure system, rapidly ascending into the atmosphere, with elemental carbon welded to heated minerals and the rest converted to $\mathrm{CO}_{2}$ and $\mathrm{NO}_{\mathrm{x}}$. As depicted in Fig. 3C, we hypothesize that the mineral substrate with or without an organic A horizon was differentially melted, some places more intensely than others.

Given the present thickness $(\sim 10 \mathrm{~cm})$ of Ah horizons in the mid-LG paleosols, little different than those hypothesized at $\sim 2$ kyr following the impact event (Fig. 3E), it is likely some surface clasts today were originally buried in the coarse clast-heavy surface, some shattered into fragments, and all eventually covered with humus as plants died off. Most recovered proxy black mat grains have been recovered from the present $\mathrm{Ah}$ and $\mathrm{Bw}$ horizons, to depths of $\sim 30 \mathrm{~cm}$ in existing profiles. Occasionally, proxy sediment has been recovered from mineral horizons lower down in the profiles to depths of $\sim 60 \mathrm{~cm}$, probably the product of movement of micron-sized grains with soil water throughput over the millennia. Given the present information available on soil profile evolution in the Guil catchment (Mahaney et al., 2016a), it appears that it takes upward of $\sim 3$ kyr to produce a B horizon (Fig. 3D) in developing soils in high and well drained sites in moraines and outwash. Because evidence of cryoturbation is not present 
in existing paleosols of the Guil/Po catchments, it seems reasonable to assume that movement of proxy sediment that was altered by the black mat event results from translocation through soils with reasonable porosity to allow entrance of at least some finer grains into the subsoil.

\section{Worldwide Record - YDB to YD}

The correlation of the black mat airburst/impact with the worldwide resurgence of ice during the $\mathrm{YD}$, following the Bølling-Allerød interstadial, has led to a decade-long controversy amongst geologists, archaeologists, chemists and astronomers as to its cause. Proponents of the correlation point to a cosmic source, given the well-dated sections with quenched/welded grains, REEs elevated above crustal averages, nanodiamonds, and high $\mathrm{Pt} / \mathrm{Pd}$ ratios at many localities (Kennett et al., 2015). Astronomers have plotted the time of Earth's encounter at $12.8 \mathrm{ka}$ with a massive 50-100-km-wide mass of ice and rock, the progenitor of Comet Encke and millions of fragments of the parent impactor, including the Taurid and $\beta$-Taurid meteor swarms. This encounter was perhaps substantial enough to keep Earth in cooling mode and allow glaciers to maintain positive mass balances for a millennium or more after the initial collision, especially if YDB airburst/impacts destabilized the Laurentide Ice Sheet and, in turn, led to major changes in thermohaline circulation in the North Atlantic, as proposed by Firestone et al. (2007). Detractors look to a slow cooling prior to $12.8 \mathrm{ka}$ and archaeologists argue that gaps exist between the time of impact and disappearance of the Clovis culture in North America. Still others, paleontologists among them, believe the disappearance of megafauna did not occur on one time-line, some species withstanding the $12.8 \mathrm{ka}$ stratigraphic marker. The result is a controversy over the cause of the YD that shows little sign of weakening, with opposing groups arguing that the evidence is anything but solid and in some cases, samples may have been contaminated and collection procedures varied widely among both proponents and deniers of the theory.

The effect of the ice resurgence is well known and documented from stratigraphic sections where YD deposits bury older mid-LG moraines (Guil River, this paper) and where ${ }^{10} \mathrm{Be}$ ages from surface clasts place the younger moraines within the YD window of 11.5-13 yr BP. More to the point, most YD dates are from surface deposits, not from full stratigraphic sections that prove YD ice actually buried older weathered sediment, peat, paleosols etc. (Mahaney, 1990). Still other evidence for the black mat comes from recovered ice and lacustrine cores, dated by ${ }^{14} \mathrm{C}$, that contain impact-altered minerals with elemental content above crustal averages and with associated chemical elements such as Sn, Pt, Ir, Os, $\mathrm{Co}$, and $\mathrm{Cl}$ that may have a cosmic origin. Still additional evidence has come from sedimentary sections in which alluvial beds with carbon encrusted grains of varying mineralogy have been shown to contain black mat sediment associated with YD till and outwash. While the cause continues to undergo rigorous debate, the ice resurgence is well documented stratigraphically, even if many continue to debate cause and effect of YDB impact $\rightarrow$ YD cooling, voicing disbelief that a cosmic impact or airburst could produce climatic forcing of a glacial resurgence for over a millennium (Pinter and Ishman, 2008; Broecker et al., 2010).

Assuming the impact/airburst is the trigger producing the YD resurgence, the early development of the Taurid meteors, and fragmental spinoff from the Encke Comet, may well have continued to force continued cooling for the time required to sustain a positive mass balance in YD ice. It is also possible that, once YD ice began to expand, it may have sustained a glacial climate for centuries by altering the microclimate, driving mean annual temperatures into negative territory (at least in the mountains of the world). In tandem with this it is also possible that iceberg calving and meltwater runoff from the Laurentide Ice Sheet caused by the impact event may have initiated a shutdown of thermohaline circulation in the North Atlantic, a widely supported hypothesis (Teller et al., 2002; Firestone et al., 2007; Lowe, et al., 2008). With attenuated ocean circulation or complete stoppage, an ocean system-wide inertia kept the thermohaline circulation from restarting within the YD time frame.

\section{Testable Hypotheses Generated From Mountain Sites}

Thus, there is the important question of whether the carbon-encrusted and REE concentrated sediment in the upper Guil and Po catchments, all dated primarily by the established time of ice withdrawal in other areas of the Western Alps, are correlative with dated beds at MUM7B in the northwestern Andes (Mahaney et al., 2013c). Significant differences exist between the two locales with barely a $3-\mathrm{cm}$ thick black encrusted bed in the Andes correlated with melted weathering rinds and dispersed elevated REEs, airburst-type sediment, and elevated $\mathrm{Pt}$ in randomly distributed horizons in paleosols that are dated only on a relative basis. Are these two evidential sedimentary horizons actually correlative and similar in most respects to the black mat seen elsewhere in North and South America, Europe, and central Asia? When originally observed during routine stratigraphic work in the Mérida Andes, the carbon-encrusted and disrupted sediment was attributed to lightning (Blackwelder, 1927; Mahaney et al., 2007, 2010), even though the prospect of achieving widespread wildfire in an initial seral stage and likely wet tundra seemed remote (Mahaney et al., 2008). Ensuing detailed laboratory evidence of the recovered samples revealed evidence suggestive of impact ejecta from local impact/airbursts producing ionizing/incandescent clouds which, in turn, twisted and melted quartz, producing possible deformation features ( $\mathrm{PFs}$ ) and planar deformation features (PDFs), glassy spherules, microspherules, and abnormally high concentrations of $\mathrm{Fe}$, albeit with no elevated Ni (Mahaney et al., 2010). Further analytical work using a FIB (focused ion beam) and TEM (transmission electron microscope) showed abnormally disrupted minerals heated 
to temperatures well in excess of $\sim 1500^{\circ} \mathrm{C}$, with the overall effect of producing considerable breccia and excessive clast fractures, as well as melted and contorted grains (Mahaney et al., 2011a, b, 2013c, 2016b). Similarities between the black mat sediment in MUM7B and experimentally-fired quartz (Mahaney et al., 2010) support a hypothesis that both intense heat and physical perturbations produced the Venezuelan grains. Both the MUM7B and experimentallyfired grains showed intense brecciation and internal fracture patterns, with brecciation more intense in the black mat samples. When compared with mid-LG samples recovered from sections in the Alps, similar grain characteristics representative of melting, quenching and fracture patterns consistent with high-energy grain collisions support a mutually conclusive impact/airburst history for both sets of samples. Affected weathering rinds, in particular, show intense effects of particle collision (Mahaney et al., 2016b) with energy vectors forcing grains in the outer rind inward to $0.7 \mathrm{~mm}$ thickness, and individual minerals formed into reoriented mineral groups with a-axes plunging deep into the clast. These reformed and reoriented minerals are often located near Fe and $\mathrm{C}$ spherules formed in clusters where they first congealed and later cooled.

While the MUM7B Andean spherules have morphological and compositional identities similar to YDB spherules documented at other sites, confirming the YDB magnetic spherule results of previous researchers (Firestone et al., 2007; Israde-Alcántara et al., 2012; Bunch et al., 2012; LeCompte et al., 2012; Wittke et al., 2013), such spherules are rare in the Alps. It is possible the absence of spherules is due to energy dissipation from the source of impact/airburst over the southern Laurentide ice sheet, or simply to limited sampling of unevenly deposited impact materials. Iron spherules carry microstructural texturing, which suggests melting and rapid quenching, modifications that could not have formed through normal/slow geological processes, such as, authigenesis, diagenesis, pedogenesis or metamorphism. Moreover, their geochemical compositions are inconsistent with volcanism and meteoritic ablation, and their depth of burial precludes anthropogenic contamination. As shown by Mahaney et al. (2013c), spherule geochemistry plots well within the limits of known impact-related materials derived exclusively from terrestrial sediments, such as tektites, ejecta, and impact spherules from a number of well-studied crater and strewnfields. Because the frequency of spherules, both in weathering rinds and paleosols in the Alps, are less than in the Andes, we hypothesize that distance from the airburst/impact probably limited spherule production. Thus, the most likely origin of the MUM7B and Alps spherules seems to be the product of a cosmic impact/airburst at $12.8 \mathrm{ka}$ with interhemispheric delivery or production at point of consequence. The MUM7B site in Venezuela, along with one in Peru, are the two southernmost sites currently known to display evidence for the YDB impact event, and these sites represent the first evidence that the effects of the impact event extended into South America, even into the Southern Hemisphere. Evidence for black mat beds in Europe is growing with two sites known in France, one along the Atlantic coast, the second identified here and in Kennett et al. (2015).

The Andean/Alps black mat samples, when compared with the experimentally-fired grains, suggest they may result from: (a) particle impact rather than heating, (b) higher initial temperatures, and/or (c) rapid cooling. Microfracture mineral patterns in the black mat samples, especially the rinds, are both parallel to and normal to the surface, the variation probably the product of impact energy or widely to narrowly spaced energy cone vectors (Mahaney et al., 2010, 2016b). As shown previously, experimentally-fired grains carry brecciated surface microfeatures close to the grain surface with internal microfracture patterns that are either aligned with crystallographic planes, as is the case with feldspars, or randomly oriented as with quartz, presumably the result of poor to indistinct cleavage with the latter mineral.

The black mat material in MUM7B, and at the French/ Italian sites, ranges from thin to thick, sometimes fibrous, carbon-rich material with accessory $\mathrm{Fe}, \mathrm{Cu}, \mathrm{Co}$ and $\mathrm{Mn}$ to glassy/opaque $\mathrm{C}$-rich spherules. The latter, often welded to grain surfaces, both in rinds (Alps) or sand clasts (Andes, Alps) in section, are covered with layers of Fe and $\mathrm{Mn}$, sometimes accompanied by $\mathrm{Cl}$ as probable ion sites in aluminosilicate glass (Stebbins and Du, 2002). Glassy carbon spherules are frequently welded to grains of variable mineralogy, producing topographically irregular forms often associated with brecciated microfeatures of some depth radiating into zones of high-frequency microfractures. These fractures are produced either by mass grain-to-grain impact, soot release from wildfires (Stich et al., 2008), or heat release. In experimentally-fired grains, heat-induced microfractures are random in quartz and variably spaced, whereas contrarily, in the MUM7B samples, microfractures are closely packed in high-density areas which possibly are produced from energy cone vectors. The black mat data derived from MUM7B samples thus far supports a kinetic theory of mass impact, the product of which produced brecciated surfaces with a high frequency of closely spaced fractures from grain-to-grain collisions at extremely high velocity, although with variable masses involved (Bunch et al., 2012). It is highly unlikely that particulate matter falling on MUM7B originated from meteor impact as far away as southern Canada. About $95 \%$ of impact ejecta falls within five crater radii and most ejecta falls off exponentially with distance (Boslough, 2012), meaning that a vanishingly small amount would have landed at the MUM7B site and a still smaller mass in the Alps.

The best explanation for the Andean and Alps samples is a local airburst that produced high speed ejecta in the fine sand to silt range, whereas the resident host grains ranged from small pebbles to coarse sand, derived from the country rock (granite gneiss in the Andes; metabasalt/mica-schist/ gabbro in France and Italy). The welded character of amorphous-C-bonded material argues for extreme heat at temperatures much higher than $900^{\circ} \mathrm{C}$, which was the firing temperature of the experimentally-tested grains but apparently not high enough to melt quartz. The exact temperature of incoming ejecta from an airburst is unknown, but 
to melt Fe that formed spherules requires temperatures of $1535^{\circ} \mathrm{C}$, and to weld amorphous $\mathrm{C}$ to grain surfaces without melting quartz requires temperatures of $\sim 1713^{\circ} \mathrm{C}$ (Frondel, 1962; Deer et al. 1966). Pyroxene, the primary mineral in the Alps samples melts at 1000 to $1400^{\circ} \mathrm{C}$ (Huebner and Turnock, 1980), the exact temperature dependent upon the particular mineral species involved. These data establish a likely maximum temperature range of $1535-1713^{\circ} \mathrm{C}$.

A number of alternative hypotheses have been invoked (Mahaney, 2013c) to explain the black mat that should be summarized here as they may relate to the French/Italian samples. First, the placon (Tilsley, 1977) in which the black mat resides in the Andes does not apply in the Alps as all evidence is in weathering rinds and paleosols, the latter all free-draining. A second hypothesis focuses on chemolithotrophic bacteria and alternating redox conditions that favor retention of $\mathrm{C}, \mathrm{Mn}$, and $\mathrm{Fe}$ which would require restricted drainage in the paleosols in France and Italy. This hypothesis relies on variations in subsurface drainage accumulation of organic and associated oxides and hydroxides without any cosmic connection (Quade et al., 1998; Pigati et al., 2012). The null hypothesis for this argument arises from the presence of melted glass and spherules, PFs and PDFs, occasional platinum based metals (PGEs), extraordinarily high monazite, and associated concentrations of rare earth elements (REEs), the latter elevated above crustal norms (Rudnick and Gao, 2005). Admittedly, the lack of definitive evidence at either site for nanodiamonds (which were not searched for) and Ir (which was not rigorously searched) and of lechatelierite weakens the cosmic hypothesis somewhat. However, the great distance between the main airburst/ impact epicenter in Canada and the distal ejecta leaves open the question of how wide the dispersal of impact/ airburst remnants might be, with the distance to the Alps being double the distance to the Andes. Third, because concentrations of ejecta vary site to site, the spatial spread is expected to be variable, all suggested by the available evidence. The spread of ejecta outward from the blast site is not expected to be uniformly distributed because concentrations decrease exponentially with distance from impact. These constraints, however, vary depending upon distance of a site to the actual airburst/impact location. Fourth, an alternative hypothesis is that organics accumulated from leaching fluids from paleosol surface horizons, with residue collected at depth (i.e. aquifer in the Andes, paleosols in the Alps), fine sediment accumulating over time with associated microbes creating a thin bed of carbon-Fe-Mn encrusted material (Bougerd and De Vrind, 1987). The null hypothesis for this argument is similar to that above, because high-temperature melted and impacted spherules and grains could not be explained by simple leaching over time. Allied to this hypothesis relates to the question of carbon spherule production resulting from fecal pellet production from mites or from secondary weathering of opal but while this may explain the carbon spherules, it does not account for the associated presence of Fe spherules, melt glass, impacted grains, presence of elevated REEs and Pt.

In the Andean samples, a preponderance of high-den- sity amorphous $\mathrm{C}$ in the great majority of samples is offset by the lack of C-rich microchondrules, which fuels an argument that the lack of chondrules in pellets negates a cosmic origin. However, this hypothesis overlooks the fact from most sites that the composition of most impact/airburst ejecta is related to target rocks rather than impactor material (Bunch et al., 2012). Comparison of the C-rich spherules in the black mat in the Andes with similar samples analyzed by Firestone et al. (2007) shows widespread similarities. C-rich spherules from other sites contain nanodiamonds, robust evidence against any nonimpact origin (Israde-Alcántara et al., 2012). The smaller C spherules from MUM7B appear less dense than those studied by Firestone et al. (2007). As a result, one could argue that the Andean pellets may have weathered or suffered ablation from distance traveled.

A last hypothesis might rely on natural high-energy wildfires to produce samples considered to be the product of cosmic heating and impact/airburst events. While both low- and high-temperature firing produces microfracturing around mineral grain edges and along crystallographic planes resulting in a micro-breccia effect, the fusion of glass-like carbon to mineral surfaces and multifarious twisted/contorted grains that result indicate the occurrence of far higher temperatures than those common in lowgrade bush fires. More importantly, no wildfire report has ever documented melting of either Si or Fe into spherules (Bunch et al., 2012). Thus, with all available evidence the only current hypothesis that explains the origin of altered and deformed minerals on several continents is the cosmic connection to the YDB. No other hypothesis, as enticing as it might be, can explain the presence of the black mat and related high-temperature proxies.

At a few sites, Firestone et al. (2007) observed that the charcoal-rich black mat itself contained abundant magnetic spherules, nanodiamonds, and other proxies. At other sites, Firestone et al. (2010) found that the impact layer lay beneath a kerogen-rich black mat of algal origin and therefore, preceded its formation. At both the Andean and Alps locations we did not find duel beds within the black mat beds and paleosol horizons analyzed, but we have found such discordances within weathering rinds, affected and disarranged minerals lying below carbon coated microbeds near the rind edge. To explain this two part structure, a seemingly contradictory situation, Firestone et al. (2007) and IsradeAlcántara et al. (2012) posited that the carbon layer above the impact layer may have formed indirectly, e.g. by algae, due to subsequent mass plant die-off and changes in temperature initiated by the onset of YD cooling. With the rind examples, however, microfractured and melted grains extend far into the rind interior without an accompanying carbon layer.

On the other hand, the black mats that contained impact proxies are posited to have formed from the direct effects of the impact event (ejecta and associated wildfires). Likewise, Mahaney et al. (2010) and this article find that the impact layer at MUM7B, containing magnetic spherules, carbon spherules, and REEs, is inextricably bound with the amorphous glass-like carbon and Fe-Mn minerals that make up the black mat-affected sediment in the Alps. The unusual 
variability of the black mat observed at MUM7B and in the Alps has not been widely reported in other paleosols, mainly it would seem because there have been few previously reported attempts to identify the YDB black mat in high mountain areas. The MUM7B site, along with a recent observation of impact ejecta, carbon encrustation, melted grains, and extreme brecciation of weathering rinds in the Alps, opens the possibility of such entities existing in other alpine areas, forming paleoenvironmental archives of the YDB impact event (Mahaney and Keiser, 2013). In other areas, where erosion might likely have removed evidence of black mat ejecta, weathering rinds in clasts on mid-LG deposits below the YD advance elevations in the Alps and other locales may remain intact as repositories of the event. At MUM7B, there is a clear relationship between the paperthin beds of the black mat and related mid-LG/YD sediment, either moraines or outwash, and this relationship cannot be dismissed out-of-hand simply because it seems to be a one-of-a-kind occurrence.

Stratigraphically, there are many examples on several continents that prove the YD glacial advance was a worldwide or near-worldwide event. To achieve something of this magnitude, the ejecta cloud resulting from several, perhaps dozens of airburst/impacts of comet fragments had to be of a size that could at least temporarily change the heat budget of the planet with sufficient magnitude to overcome the warming trend of the Bølling-Allerød interstadial. To help accomplish such a change in the heat budget of the planet, the impact/airburst could have been responsible for the well-documented interruption of thermohaline circulation in the North Atlantic, such coupled atmosphere/marine disruptions producing interhemispheric consequences (Broecker et al., 2010). That the YD cooling episode was interhemispheric is beyond question, given the mounting evidence from a multidude of sites, includind recent evidence from Antarctia (Wolbach et al., 2018a, and Mahaney et al., in press).

Sequentially, as indicated in Fig. 3A and B, the stillstand positions of the retreating Allerød ice left a surface with thin soils only centuries into morphogenesis. That mainly lithic substrate was subjected to the heat and pressure of the major airburst/impact that produced the YDB bed shown in Fig. 3C, eventually morphing into a thicker and somewhat better developed Entisol 2 kyr later at approximately $\sim 11 \mathrm{ka}$ (Fig. 3D). Given what is known of soil morphogenesis over the Neoglacial in the Guil catchment (Mahaney et al., 2016a), it is likely the post-YDB soil at this time did not have a B horizon and since in the waning centuries of the Late Glacial climate was cooler and drier than during the middle to Late Holocene. In all likelihood, the soil at time of impact/airburst was a thin profile, albeit with considerable fallout residue incoming from the $12.8 \mathrm{ka}$ event. The ensuing soil development during the waning centuries of the Late Glacial and through the Holocene produced the surface seen today (Fig. 3E) and its accompanying paleosol (Fig. 3F), the latter similar in composition to the profiles depicted in Fig. 2.

Resident organic matter and developing microbes within the Alps soils at time of impact/airburst would have been volatilized, gasified or welded onto mineral grains as indicated by the databases presented here and in other publications (Mahaney and Keiser, 2013; Mahaney et al., 2013b). Because the black mat has never previously been identified in paleosols elsewhere, its stratigraphic presence in mid-LG surface sediments, relative to YD moraines, offers a first-time opportunity to search for a microbiological stamp or signature in microbe populations caused by the conflagration produced by the cosmic event through comparative microbial ecology studies. To date any relationship between the structure of present day microbial communities in sediments and the black mat are almost completely absent from the literature. While most bacteria, indeed most organic matter, must have been lost since deposition from the comet, it is possible the ingress of cosmic materials $\mathrm{Pt}$, elevated REEs, $\mathrm{Sn}$, elevated $\mathrm{Fe}, \mathrm{Co}, \mathrm{Cu}, \mathrm{Cr}$, and $\mathrm{Cl}$ in Al-glass - and incandescent, albeit instantaneous, temperature flux might have effectively reset the microbe clock, its time-adjustment still present within the genetic makeup of resident bacteria present within the mid-LG paleosols. This possibility is linked to the emerging study of geomicrobiology processes and a realization that geological time and microbiological time may be related. The search for a microbe signal connected with the BM is elusive, has been tentatively found using DGGE analysis (Mahaney et al., 2013b), but has so far eluded detection using metagenome analysis. Future studies may well yield positive results using ongoing total deep-metagenome sequencing and transcriptomic/metabolomic methods. Variations in the distribution of genes, rather than bacterial populations, resulting from elevated REES and Pt, are possibly more than mere hypothetical constructs and the pursuit continues. If such a microbial transformation were to be found, it would not only strengthen the evidence supporting the black mat hypothesis, but it would have a much wider application to our understanding of how the early bombardment of Earth by meteorites and comets affected the evolutionary vector of early transient microbes. The Guil/Viso paleosol sites identified in this study may yet serve as a remarkable resource for the study of these intriguing phenomena.

\section{CONCLUSIONS}

As demonstrated with this work, paleosols provide substantial archives of cosmic impact/airburst records, i.e. the black mat event, making it imperative to establish a probable pathway of soil profile evolution following the retreat of mountain glaciation, ca $\sim 15 \mathrm{ka}$. Normal soil stratigraphic relationships from the LIA to the middle Holocene (2-3 kyr trend) provides baseline data that can be used to estimate what profile thickness and other soil properties probably existed at time of impact. With a $\sim 2 \mathrm{kyr}$ weathering time trend following the start of deglaciation, the retreating Würm ice probably established stillstand positions around $\sim 13.5-13 \mathrm{ka}$. This means that with approximately $\sim 500 \mathrm{yr}$ of weathering, soils in situ at the time of impact/ 
airburst likely were thin, normally no thicker than $\sim 15-20$ $\mathrm{cm}$, and with $\mathrm{C} / \mathrm{Cu}$ and or perhaps at most $\mathrm{Cox} / \mathrm{Cu}$ profiles, possibly also with thin A horizons in places. If present at time of impact/airburst, Ah horizons would be expected to contain $<5 \%$ organic carbon, with particle size little different than underlying $\mathrm{C}$ horizons, typically coarse sandy loam, and a mineralogy (olivine-pyroxene-amphibole-Ca-plagioclase) similar to what would have existed in the mineral substrate from which the profile developed. If, in existence at time of impact/airburst, these thin Ah horizons would have been volatilized and/or welded to mineral grains, such affected mineral grains partially melted, even welded together, as shown by previous SEM investigations of black mat sediment.

To date, the evidence for an airburst/impact effect on incipient microbe development at the end of the Allerød remains tentative, while the continuing search for a metagenomic profile, correlated to specific chemical elements or groups of elements in mid-LG sediments, remains a testable hypothesis with far reaching implications. Such a hypothesis rests on the premise that a gasified/volatile carbon, energized at extremely high temperatures, interacting with a volatile chemical-mineral mix, may have produced an anomalous short term flux in microbial community structure, evidence of which is resident still in the mid-LG paleosols. The previous DGGE findings itemized in Mahaney et al. (2013b) suggest, at least, the possibility that such a record still exists.

The scenario reconstructed from this work indicates the probability that organic carbon was present in minimal amounts and probably widely scattered in the foreland of the retreating Late Glacial ice with a terminus in the Alps above $2400 \mathrm{~m}$ asl, perhaps as high as $2800 \mathrm{~m}$ asl or close to the Col de la Traversette $(3000 \mathrm{~m})$ at the head of the cirque. With little plant cover and low organic carbon resident in sediment at the time of the impact/airburst event, it is remarkable that most sites contain copious amounts of glassy carbon spherules or opaque carbon left over from the black mat event, which suggests some of the carbon could be imported terrestrial or cosmic material. Because most evidence of impact/airburst is found in the present Bw horizons and lower down in the paleosols in the Cox, and sometimes the $\mathrm{Cu}$ horizons, these largely mineral-rich horizons were the former $\mathrm{C} / \mathrm{Cu}$ or $\mathrm{A} / \mathrm{C} / \mathrm{Cu}$ horizons in existence at $12.8 \mathrm{ka}$. Widely dispersed and elevated REE concentrations, along with high $\mathrm{Pt} / \mathrm{Pd}$ concentrations and airburstaltered grains probably result from subtle differences in throughput of moisture profile-to-profile, pebble-sand clast orientation, sediment porosity variation, and enveloping plant cover following the impact/airburst. All of these acted together to provide profile stability and dictate redistribution of affected minerals as shown in the time sequence of Fig. 3. Pebbles embedded in the surface Ah horizons carry archives of the impact/airburst, the organic component developing at some point after the surface cooled to ambient temperature regimes, unlike the coarse clastic material that is a post-event addition to the sediment mix.

\section{Acknowledgments}

This research was funded by Quaternary Surveys, Toronto and York University Grant 493885. We thank the CAMCOR team, University of Oregon, for use of the NSF-funded FIB-SEM and TEM. P. Somelar was funded by Estonian Research Council grant PUT1511.

\section{REFERENCES}

Andersson, G., 1896. Svenska Växtvärldens Historia. P.A. Norstedt \& Söner, Stockholm, 278 pp.

Andronikov, A.V., Andronikova, I.E. Loehn, C.W., LaFuente, B., Ballengaer, J.A.M., Crawford, G.T., Lauretta, D.S., 2016a. Implications from chemical, structural and mineralogical studies from around the lower Younger Dryas Boundary (New Mexico, USA). Geografiska Annaler: Series A, Physical Geography 98, 39-59.

Andronikov, A.V., Van Hoesel, A., Andronikova, I.E., Hoek, W.Z., 2016b. Trace element distribution and implications in sediments across the Allerod - Younger Dryas Boundary in the Netherlands and Belgium. Geografiska Annaler: Series A, Physical Geography 98, 325-345.

Birkeland, P.W., 1999. Soils and Geomorphology. Oxford University Press, Oxford, UK, 430 pp.

Blackwelder, E., 1927. Fire as an agent in rock weathering. Journal of Geology 35, 134-140.

Boslough, M., 2012. Inconsistent impact hypotheses for the Younger Dryas. Proceedings of the National Academy of Sciences USA 109 (34), E2241, doi:10.1073/pnas.1206739109.

Bougerd, F.C., De Vrind, J.M.P., 1987. Manganese oxidation by Leptothrix discophora. Journal of Bacteriology 169, 489-494.

Broecker, W.S., Denton, G.H., Edwards, R.L., Cheng, H., Alley, R.B., Putnam, A.E., 2010. Putting the Younger Dryas cold event into context. Quaternary Science Reviews 29, 1078-1081.

Bunch, T.E., Hermes, R.E., Moore, A.M.T., Kennett, D.J., Weaver, J.C., Wittke, J.H., DeCarli, P.S., 2012. Very high-temperature impact melt products as evidence for cosmic airbursts and impacts 12,900 years ago. Proceedings of the National Academy of Sciences USA 109, E1903-E1912.

Canada Soil Survey Committee (CSSC), 1998. The Canadian System of Soil Classification. 637 NRC Research Press, Ottawa, Canada (Publ. 1646), $187 \mathrm{pp}$

Cossart, E., Fort, M., Bourles, D., Carcaillet, J., Perrier, R., Siame, L., Braucher, R., 2010. Climatic significance of glacier retreat and rock glaciers re-assessed in the light of cosmogenic dating and weathering rind thickness in Clarée valley (Briançonnais, French Alps). Catena 80, 204-219.

Day, P.E. 1965. Particle fractionation and particle size analysis. In: Black, C.A. (Ed.), Methods of soil analysis. American Society of Agronomy, Madison, WI, 545-567.

Deer, W.A., Howie, R.A., Zussman, J., 1966. An introduction to the rock forming minerals. Longman, London, 340-355.

De Laeter, J.R., Jeffery, P.M., 1965. The isotopic composition of terrestrial and meteoritic tin. Journal Geophysical Research 70 (12), 2895-2903.

Dumont T., Schwartz S., Guillot S., Simon-Labric T., Tricart P., Jourdan S., 2012. Structural and sedimentary records of the Oligocene revolution in the Western Alps. Journal of Geodynamics 56-57, $18-38$.

Finsinger, W., Lane, C.S., van den Brand, G.J., Wagner-Cremer, F., Blockley, S.P.E., Lotter, A.F., 2011. The Lateglacial Quercus expansion in the southern European Alps: rapid vegetation response to a late Allerød warming. Journal of Quaternary Science 26, 694-702.

Firestone, R.B., West, A., Kennett, J.P., Becker, L., Bunch, T.E., Revay, Z.S., Schultz, P.H., Belgya, T., Kennett, D.J., Erlandson, J.M., 
Dickenson, O.J., Goodyear, A.C., Harris, R.S., Howard, G.A., Kloosterman, J.B., Lechler, P., Mayewski, P.A., Montgomery, J., Poreda, R., Darrah, T., Que Hee, S.S., Smith, A.R., Stich, A., Topping, W., Wittke, J.H., Wolbach, W.S., 2007. Evidence for an extraterrestrial impact 12,900 years ago that contributed to the megafaunal extinctions and the Younger Dryas cooling. Proceedings of the National Academy of Sciences USA 104, 16016-16021.

Firestone, R.B., West, A., Revay, Z., Hagstrum, J.T., Belgya, T., Gue Hee, S.S., Smith, A.R., 2010. Analysis of the Younger Dryas impact layer. Journal of the Siberian Federal University, Engineering \& Technologies 1 (3), 30-62.

Frondel, C., 1962. Dana's system of mineralogy (Vol. II). Silica minerals. Wiley, New York, $334 \mathrm{pp}$.

Grapes, R. 2010., Pyrometamorphism. Springer, Berlin, 329 pp.

Hartz, I., Milthers, V. 1901. Det senglacie ler i Allerød tegelværksgrav. Meddelelser Danks Geologisk Foreningen 8, 31-60.

Haynes, C.V., Jr., Boerner, J., Domanik, K., Lauretta, D., Ballenger, J., Goreva, J., 2010. The Murray Springs Clovis site, Pleistocene extinction, and the question of extraterrestrial impact. Proceedings of the National Academy of Sciences USA 107 (9), 4010-4015.

Hodgson, J.M., 1976. Soil Survey Field Handbook - Soil Survey Technical Monograph, No. 5. 773 Rothamsted Experimental Stn, Harpenden, Herts, 99 pp.

Huebner, J.S., Turnock, A.C., 1980. The melting relations at 1 bar of pyroxenes composed largely of $\mathrm{Ca}-\mathrm{Mg}$ - and Fe-bearing components. American Mineralogist 65, 225-271.

Israde-Alcántara, I., Bischoff, J.L., Dominquez-Vazquez, G., Li, H.-C., DeCarli, P.S., Bunch, T.E., Wittke, J.H., Weaver, J.C., Firestone, R.B., West, A., Kennett, J.P., Mercer, C., Xie, S., Richman, E.K., Kinzie, C.R., Wolbach, W.S., 2012. Evidence from Central Mexico supporting the Younger Dryas extraterrestrial impact hypothesis. Proceedings of the National Academy of Sciences USA 109, E738-E747.

Kennett, J.P., Becker, L., West, A., 2007. Triggering of the Younger Dryas Cooling by extraterrestrial impact. AGU Annual Meeting, 2007, PP41A-05.

Kennett, D.J., Kennett, J.P., West, A., Mercer, C., Que Hee, S.S., Bement, L, Bunch, T.E., Sellers, M., Wolbach, W.S., 2009. Nanodiamonds in the Younger Dryas Boundary Sediment. Science 323 (5910), 94

Kennett, J.P., Kennett, D.J., Culleton, B.J., Tortosa, J.E.A., Bischoff, J.L., Bunch, T.E., Daniel, I.R., Erlandson, J.M., Ferraro, D., Firestone, R.B., Goodyear, A.C., Israde-Alcántara, I., Johnson, J.R., Jordá Pardo, J.F., Kimbel, D.R., LeCompte, M., Lopino, N.H., Mahaney, W.C., Moore, A.M.T., Moore, C.R., Ray, J.H., Stafford, T.W. Jr., Tankersley, K.B., Wittke, J.H., Wolbach, W.C., West, A., 2015. Bayesian chronological analyses consistent with synchronous age of 12,835-12,735 Cal B.P. for Younger Dryas boundary on four continents, doi: 10.1073/pnas.1507146112.

Lanari, P., Rolland, Y., Schwartz, S., Vidal, O., Guillot, S., Tricart, P., Dumont, T., 2014. P-T-t estimation of syn-kinematic strain in low-grade rocks $\left(<300^{\circ} \mathrm{C}\right)$ using thermodynamic modelling and 40Ar/39Ar dating techniques: example of the Plan-de-Phasy shear zone (Briançonnais Zone, Western Alps). Terra Nova 26, 130-138.

Lardeaux, J.M., Schwartz, S., Tricart, P., Paul, A., Guillot, S., Béthoux, N., Masson, F., 2006. A crustal-scale cross-section of the southwestern Alps combining geophysical and geological imagery. Terra Nova 18 (6), 412-422.

LeCompte, M.A., Goodyear, A.C., Demitroff, M. N., Batchelor, D., Vogel, E.K., Mooney, C., Rock, B.N., Seidel, A.W., 2012. An independent evaluation of conflicting microspherule results from different investigations of the Younger Dryas impact hypothesis. Proceedings of the National Academy of Sciences USA 106, doi: 10.1073/pnas. 1208603109.

Lemoine, M., Bas, T., Arnaud-Vanneau, A., Arnaud, H., Dumont, T., Gidon, M., Bourbon, M., de Graciansky, P.C., Rudkiewicz, J.L.,
Megard-Galli, J., Tricart, P., 1986. The continental margin of the Mesozoic Tethys in the Western Alps. Marine and Petroleum Geology 3, 179-199.

Lowe, J.J., Rasmussen, S.O., Björck, S., Hoek, W.Z., Steffensen, J.P., Walker, M.J.C., Yu, Z.C., 2008. Synchronisation of palaeoenvironmental events in the North Atlantic region during the Last Termination: a revised protocol recommended by the INTIMATE group. Quaternary Science Reviews 27, 6-17.

Mahaney, W.C., 1990. Ice on the Equator. Wm Caxton Ltd., Ellison Bay, Wisc, 386 pp.

Mahaney, W.C., 1991. Later Pleistocene and Holocene glacial chronology at Chamonix and Argentière, French Alps, in Zeitschrift für Geomorphologie 35 (2), 225-237.

Mahaney W.C., 2002. Atlas of sand grain surface textures and applications. Oxford University Press, Oxford, $237 \mathrm{pp}$.

Mahaney, W.C., Keiser, L., 2013. Weathering rinds: unlikely host clasts for evidence of an impact-induced event. Geomorphology 184, 74-83.

Mahaney, W. C., Milner, M.W., Sodhi, Rana, Dorn R. I., Boccia, S., Beukens, R.P., Tricart, P., Schwartz, S., Chamorro-Perrez, E., Barendregt, R.W., Kalm, V., Dirszowsky, R.W., 2007, Analysis of burnt schist outcrops in the Alps: relation to historical archaeology and Hannibal's crossing. Geoarchaeology 22, 797-816.

Mahaney, W.C., Milner, M.W., Kalm, V., Dirzowsky, R.W., Hancock, R.G.V., Beukens, R.P., 2008. Evidence for a Younger Dryas glacial advance in the Andes of northwestern Venezuela. Geomorphology 96, 199-211.

Mahaney, W.C., Kapran, B., Milner, M.W., Kalm, V., Krinsley, D., Beukens, R., Boccia, S., Hancock, R.G.V., 2010. Evidence from the northwestern Venezuelan Andes for extraterrestrial impact: the black mat enigma. Geomorphology 116, 48-57.

Mahaney, W.C., Krinsley, D., Langworthy, K., Hart, K., Kalm, V., Tricart, P., Schwartz, S., 2011a. Fired glaciofluvial sediment in the northwestern Andes: biotic aspects of the Black Mat. Sedimentary Geology 237 (1-2), 73-83.

Mahaney, W.C., Krinsley, D., Dohm, J., Kalm, V., Langworthy, K., Ditto, J., 2011b. Notes on the black mat sediment, Mucuñuque catchment, northern Mérida Andes, Venezuela. Journal of Advanced Microscopy Research 6 (3), 177-185.

Mahaney, W.C., Krinsley, D.H., Allen, C.C.R., 2013a. Biomineralization of weathered rock rinds: examples from the lower Afroalpine zone on Mount Kenya. Geomicrobiology Journal 30 (5), 411-421.

Mahaney, W.C., Keiser, L., Krinsley, D.H., Pentlavalli, P., Allen, C.C.R., Somelar, P., Schwartz, S., Dohm, M.J., Dirzowsky, R., West, A., Julig, P., Costa, P., 2013b. Weathering rinds as mirror images of palaeosols: examples from the Western Alps with correlation to Antarctica and Mars. Journal of the Geological Society of London 170, 833-847.

Mahaney, W.C., Keiser, L., Krinsley, D., Kalm, V., Beukens, R., West, A., 2013c. New Evidence from a Black Mat Site in the northern Andes supporting a cosmic impact 12,800 Years Ago. Journal of Geology 121 (6), 591-602.

Mahaney, W.C., Somelar, P., Dirszowsky, R.W., Kelleher, B., Pentlavalli, P., McLaughlin, S., Kulakova, A.N., Jordan, S., Pulleyblank, C., West, A., Allen, C.C.R., 2016a. A microbial link to weathering of postglacial rocks and sediments, Mt. Viso area, Western Alps, demonstrated through analysis of a soil/paleosol bio/chronosequence. Journal of Geology 124, 149-169.

Mahaney, W.C., Krinsley, D.H., Razink, J., Fischer, R., Langworthy, K., 2016b. Clast rind analysis using multi-high resolution instrumentation. Scanning 38, 202-212.

Mahaney, W.C., Somelar, P., West, A., Krinsley, D., Allen, C.C.R., Pentlavalli, P., Young, J.M., Dohm, J.M., LeCompte, M., Kelleher, B.J.S., Pulleyblank, C., Dirszowsky, R., Costa, P., 2017. Evidence for cosmic airburst/impact in the Western Alps archived in Late Glacial Paleosols. Quaternary International 438 (B), 68-80. 
Mahaney, W.C., Krinsley, D., Milner, M.W., Fischer, R., Langworthy, K., in press. Did the Black Mat Impact/Airburst reach the Antarctic: Evidence from the New Mountain area near the Taylor Glacier in the Dry Valley Mountains. Journal of Geology.

Meltzer, D.J., Holliday, V.T., Cannon, M.D., Miller, S.D., 2014. Chronological evidence fails to support claim of an isochronous widespread layer of cosmic impact indicators dated to 12,800 years ago, Proceedings of the National Academy of Sciences USA, doi: 10.1073/pnas.1401150111.

National Soil Survey Center (NSSC), 1995. Soil Survey Laboratory Information Manual. Soil Survey Investigations Report No. 45. Version 1.00. USDA, Washington, D.C., 305 pp.

Oyama, M., Takaehara, H., 1970. Standard Soil Color Charts. Japan Research Council for Agriculture and Fisheries.

Petaev, M.I., Huang, S., Jacobsen, S.B., Zindler, A., 2013. Large Pt anomaly in the Greenland ice core points to a cataclysm at the onset of Younger Dryas. Proceedings of the National Academy of Sciences USA 110 (32), 12917-12920.

Pigati, J.S., Latorre, C., Rech, J.A., Betancourt, J.L., Martinez, K.E., Budahn, J.R., 2012. Accumulation of "impact markers" in desert wetlands and implications for the Younger Dryas impact hypothesis. Proceedings of the National Academy of Sciences USA 109: 7208-7212.

Pinter, N., Ishman, S.E., 2008. Impacts, mega-tsunami, and other extraordinary claims. GSA Today 18, 37-38.

Quade, J., Forester, R.M., Pratt, W.L., Carter, C., 1998. Black mats, spring-fed streams, and Late Glacial Age recharge in the southern Great Basin. Quaternary Research 49, 129-148.

Ralska-Jasiewiczowa, M., Stebich, M., Negendank, J.F.W., 2001. Correlation and synchronization of Lateglacial continental sequences in northern central Europe based on annually laminated lacustrine sediments. Quaternary Science Reviews 20, 1233-1249.

Rudnick, R.L., Gao, S., 2005. Composition of the continental crust. In: Rudnick, R.L. (Ed.), The Crust: Treatise on Geochemistry. Elsevier, Amsterdam, 1-64.

Schwartz, S., Lardeaux J.M., Guillot S., Tricart P., 2000. The diversity of eclogitic metamorphism in the Monviso ophiolitic complex, western Alps, Italy. Geodinamica Acta 13, 169-188.

Schwartz, S., Guillot S., Reynard B., Lafay R., Debret B., Nicollet C., Lanari P., Auzende A.L., 2013. Pressure-temperature estimates of the lizardite/antigorite transition in high pressure serpentinites. Lithos 178, 197-210.

Schwartz, S., Tricart, P., Lardeaux, J.M., Guillot, S., Vidal, O., 2009. Late tectonic and metamorphic evolution of the Piedmont accretionary wedge (Queyras Schistes lustrés, western Alps): Evidences for tilting during Alpine collision. Geological Society of America Bulletin 121 (3/4), 502-518.

Stebbins, J. F., Du, L.-S., 2002. Chloride ion sites in silicate and aluminosilicate glasses: a preliminary study by ${ }^{35} \mathrm{Cl}$ solid state NMR. American Mineralogist 87, 359-363.

Stich, A., Howard, G., Kloosterman, J. B. Firestone, R.B., West, A., Kennett, J.P., Kennett, D.J., Bunch, T.E., Wolbach, W.S., 2008. Soot as evidence for widespread fires at the Younger Dryas onset (YDB; 12.9 ka). American Geophysical Union fall meeting, abstract PP13C-1471.

Teller, J.T., Leverington, D.W., Mann, J.D., 2002. Freshwater outbursts to the oceans from glacial Lake Agassiz and their role in climate change during the last deglaciation. Quaternary Science Reviews 21, 879-887.

Thiagarajan, N., Subhas, A.V., Southon, J.R., Eiler, J.M., Adkins, J.F., 2014. Abrupt pre-Bølling-Allerød warming and circulation change in the deep ocean. Nature 511, 75-78.

Tilsley, J.E., 1977. Placosols: another problem in exploratory geochemistry. Journal of Geochemical Exploration 7, 21-30.

Tricart, P., Schwartz, S., 2006. A north-south section across the Queyras Schistes lustrés (Piedmont zone, Western Alps): syncollision refolding of a subduction wedge. Eclogae Geologicae Helvetia 99, 429-442.

Tricart, P., Schwartz, S., Lardeaux, J.-M., Thouvenot, F., du Chaffaut, S.A., 2003, Aiguilles-Col Saint-Martin, Carte Géologique de la France, 1:50000.

Tricart, P., 1984. From passive margin to continental collision: a tectonic scenario for the Western Alps. American Journal of Science $284,97-120$.

Van der Hammen, T., Van Geel, B., 2008. Charcoal in soils of the Allerød-Younger Dryas transition were the result of natural fires and not necessarily the effect of an extra-terrestrial impact. Netherlands Journal of Geosciences 87, 359-361.

Walkley, A., Black, I.A., 1934. An examination of the Degtjareff method for determining soil organic matter, and a proposed modification of the chromic acid titration method. Soil Science 37, 29-38.

Wolbach, W.S., Ballard, J.P., Mayewski, P.A., Parnell, A.C., Cahill, N., Adedeji, V., Bunch, T.E., Domínguez-Vázquez, G., Erlandson, J.M., Firestone, R.B., French, T.A., Howard, G., Israde-Alcántara, I., Johnson, J.R., Kimbel, D., Kinzie, C.R., Kurbatov, A., Kletetschka, G., LeCompte, M.A., Mahaney, W.C., Melott, A.L., Mitra, S., Maiorana-Boutilier, A., Moore, C.R., Napier, W.M., Parlier, J., Tankersley, K.B., Thomas, B.C., Wittke, J.C., West, A., Kennett, J.P., 2018a. Extraordinary Biomass-Burning Episode and Impact Winter Triggered by the Younger Dryas Cosmic Impact $~ 12,800$ Years Ago. 1. Ice Cores and Glaciers. Journal of Geology126 (2), 165-184.

Wolbach, W.S., Ballard, J.P., Mayewski, P.A., Parnell, A.C., Cahill, N., Adedeji, V., Bunch, T.E., Domínguez-Vázquez, G., Erlandson, J.M., Firestone, R.B., French, T.A., Howard, G., Israde-Alcántara, I., Johnson, J.R., Kimbel, D., Kinzie, C.R., Kurbatov, A., Kletetschka, G., LeCompte, M.A., Mahaney, W.C., Melott, A.L., Mitra, S., Maiorana-Boutilier, A., Moore, C.R., Napier, W.M., Parlier, J., Tankersley, K.B., Thomas, B.C., Wittke, J.C., West, A., Kennett, J.P., 2018b. Extraordinary Biomass-Burning Episode and Impact Winter Triggered by the Younger Dryas Cosmic Impact $~ 12,800$ Years Ago.2. Lake, Marine, and Terrestrial Sediments, Journal of Geology 126 (2), 185-205.

Wittke, J.H., Weaver, J.C., Bunch, T.E., Kennett, J.P., Kennett, D.J., Moore, A.M.T., Hillman, G.C., Tankersley, K.B., Goodyear, A.C., Moore, C.R., Daniel, R., Jr., Ray, J.H., Lopinot, N.H., Ferraro, D., Israde-Alcántara, I., Bischoff, J.L., DeCarli, P.S., Hermes, R.E., Kloosterman, J.B., Revay, Z., Howard, G.A., Kimbel, D.R., Kletetschka, G., Nabelek, L., Lipo, C.P., Sakai, S., West, A., Firestone, R.B,. 2013. Evidence for deposition of 10 million tonnes of impact spherules across four continents 12,800 years ago. Proceedings of the National Academy of Sciences USA, doi: 10.1073/ pnas. 1301760110. 